\title{
Exporting the German Model: the Establishment of a New Automobile Industry Cluster in Shanghai, P.R. China
}

\author{
Heiner Depner \& Harald Bathelt
}

\author{
Version Post-print/accepted manuscript \\ Citation Depner, H., \& Bathelt, H. (2005). Exporting the German model: The \\ (published version) establishment of a new automobile industry cluster in Shanghai. \\ Economic Geography, 81(1), 53-81. \\ Copyright / License \\ Publisher's Statement This is the peer reviewed version of the following article: [Depner, H., \\ \& Bathelt, H. (2005). Exporting the German model: The establishment \\ of a new automobile industry cluster in Shanghai. Economic Geography, \\ 81(1), 53-81.], which has been published in final form at: \\ http://onlinelibrary.wiley.com/doi/10.1111/j.1944- \\ $\underline{8287.2005 . t b 00255 . x / a b s t r a c t}$ \\ This article may be used for non-commercial purposes in accordance \\ with Wiley Terms and Conditions for Self-Archiving.
}

Always cite the published version, so the author(s) will receive recognition through services that track citation counts, e.g. Scopus. If you need to cite the page number of the TSpace version (original manuscript or accepted manuscript) because you cannot access the published version, then cite the TSpace version in addition to the published version using the permanent URI (handle) found on the record page. 
May 9, 2004

\title{
Exporting the German model:
}

\section{the establishment of a new automobile industry}

\author{
cluster in Shanghai, P.R. China ${ }^{1}$
}

\author{
Heiner Depner \\ Faculty of Geography, Philipps-University of Marburg, \\ Deutschhausstraße 10, D-35032 Marburg, Germany, \\ Phone: +49 +6421 28 26543, Fax: +49 +6421 28 28950, \\ E-Mail: depner@staff.uni-marburg.de \\ $\&$

\section{Harald Bathelt} \\ Faculty of Geography, Philipps-University of Marburg, \\ Deutschhausstraße 10, D-35032 Marburg, Germany, \\ Phone: +49 +6421 28 24211, Fax: +49 +6421 2828950 , \\ E-mail: bathelt@staff.uni-marburg.de, \\ URL: www.harald-bathelt.de
}

\footnotetext{
${ }^{1}$ Acknowledgements: An earlier version of this paper was presented at the 2003 Annual Meeting of the Association of American Geographers in New Orleans. We would like to thank numerous participants of this meeting for their comments and suggestions. Our special thanks go to Gang Zeng for stimulating discussions on core issues of this paper and for his overwhelming hospitality during our research trips to China. We would also like to thank Weihua Je for organizational support in Shanghai and Clare Wiseman for making her usual decisive comments at all stages of the research process. We are further indebted to Bjorn Asheim and Meric Gertler, as well as two anonymous reviewers for their valuable comments. Thanks are also due to the Deutsche Forschungsgemeinschaft (German Science Foundation) for providing the funds which allowed us to conduct this research and present it to colleagues. Finally, we would like to thank those executives and managers of German and Chinese firms for their interest and time they shared with us in answering our questions. Without their support, this study would not have been possible.
} 


\title{
Exporting the German model: the establishment of a new automobile industry cluster in Shanghai, P.R. China
}

\begin{abstract}
Recent work has provided evidence that the establishment of new industry clusters can hardly be jump-started through policy initiatives alone. This does not, however, imply that the genesis of a new cluster cannot be planned at all. Especially in the context of a developing economy, it seems useful to re-investigate the relation between economic development, multinational firm strategies and state intervention in this respect. Drawing from the case of the automobile industry and its supplier system in Shanghai in which German firms play an important role, we will provide empirical evidence for the evolution of a new cluster which is supported by the state in various forms and characterized by a focal, hierarchically-structured production system. We use a multi-dimensional approach to clusters, which provides a more nuanced understanding of the evolution and growth of a cluster than that provided by earlier accounts. This approach allows us to distinguish the development of the Shanghai automobile industry cluster along its vertical, horizontal, external, institutional and power dimensions. We provide evidence that another dimension, i.e. 'culture', plays an important role, especially in its relation to issues of power and institutions. This is demonstrated in the case of German firms, which tap into the Chinese innovation system. This system is characterized by particular business relations, institutions, norms and various social practices which are new to German firms. We will demonstrate how this difference creates problems in establishing local production and supplier relations and how these can be overcome.
\end{abstract}

Keywords: clusters, institutions, inter-cultural communication, boundary spanners, automobile industry, Shanghai 


\section{Introduction}

In recent years, one of the hotbeds of research in sociology, economics, political science and economic geography has been to analyze the establishment of clusters of interrelated firms, their continued growth and the way how they secure reproduction. From a study of a larger number of industrial clusters in different parts of the world, Bresnahan, Gambardella and Saxenian (2001) found, for instance, that the reasons behind the establishment of a new cluster are much different from those which support the growth of an existing cluster. In their comparative study of information and communication technology clusters, they found that external effects, agglomeration factors and networking synergies were primarily important in the later stages of growth. In contrast, outstanding entrepreneurial activities, the willingness to accept risk in starting up new ventures and the ability to tap into areas outside the established technologies and access major markets had been decisive for the genesis of clusters. Bresnahan, Gambardella and Saxenian (2001) emphasized from their research that state policy did not have a substantial influence on the establishment of the clusters studied. According to their work, the degree of openness in regional economic relations and active searching for large external markets is key in understanding the rise of successful clusters.

Although we agree with this study on most accounts, we are somewhat skeptical about the generality of its conclusions. There are examples which show how this conclusion can be misleading (e.g. Lundequist and Power 2002). Especially in the case of the automobile industry, the situation is somewhat different. The automobile industry is characterized by a hierarchical social division of labor, organized in tiers around powerful car producers. Although this focal production network is far from being a simple top-down hierarchy, it is characterized by very strong ties and uneven power relations. The car producers are a primary force driving the organization of the production system and its spatial manifestations. When they establish production facilities in a country where they cannot find complementary 
suppliers, they urge their key suppliers to also establish plants in the host country, preferably close-by (Florida and Kenney 1991, Depner and Dewald 2004). Due to their organization around a focal company, automobile suppliers are responsive to cluster formation when entering new market regions. This development is largely planned. In addition, it would be somewhat naive to ignore political influences. They might not be the major force driving the genesis of clusters in industrial countries, but they are of decisive importance in countries such as the People's Republic of China which still has some characteristics of a planned economy.

As Humphrey and Schmitz (2002) have pointed out, there are basically two different conceptions which could be used as a basis to study the process of how industries extend their production networks to other countries, i.e. clusters and global commodity chains. Each of these approaches is associated with particular problems in this context. The cluster concept (Porter 1998, 2000) explains economic success by drawing on the internal structure of social relations between local or regional firms while neglecting extra-local linkages. In contrast, the concept of global commodity chains (Gereffi 1994, 1999) emphasizes the advantages of international production organization and governance structures but underestimates the territorial dimension and the localized nature of production arrangements. Gereffi's (1994) approach primarily focusses on a very specific form of governance (i.e. buyer-driven commodity chains) and says little about the spatiality of global commodity chains. In order to bring both perspectives closer together, Dicken, Kelly, Olds and Yeung (2001) and Henderson, Dicken, Hess, Coe and Yeung (2002) have developed a concept of global production networks which is spatially sensitive because it builds on actor-networks and social and territorial embeddedness. In this paper, we suggest that a cluster concept - if used with care can be employed in an useful way to complement existing work on global production networks. When car producers establish large production facilities in host countries which do not provide complementary capabilities and institutions, the producers aim to create favorable 
conditions themselves. Often this is done by acting upon suppliers to establish production facilities in the host country, thus drawing upon the same institutions as in their home country's innovation system. In the case of the automobile industry, this may lead to clustering processes (Mair, Florida and Kenney 1988, Ó hUallacháin and Wasserman 1999). There are additional reasons to favor a cluster approach in the context of this study, i.e. the establishment and growth of the automobile industry in Shanghai. Firstly, the organization of this industry in Shanghai around Volkswagen (VW) and General Motors (GM) is highly localized. This is the result of an interplay between foreign car producers, which aimed to upgrade their local supplier base in order to produce high-quality cars, and governmental authorities, which put pressure on the car producers to establish local supplier linkages to boost the domestic car industry. Secondly, the developing production cluster and localized producer-user relations in the automobile industry, although by no means forming a purely regional ensemble of industrial relations, are more persistent than those in fashion-related consumer-goods industries, such as textiles, footwear and apparel (e.g. Gereffi and Korzeniewicz 1990, Gereffi 1994, 1999). Thirdly, the approach is well suited to explain cluster formation in response to high spatial transaction costs and difficulties to realize untraded interdependencies in an inter-cultural context. ${ }^{2}$

Through the application of this approach, we aim to contribute to a better understanding of Asian economics and economic geographies (Yeung and Lin 2003).Specifically, the primary goals were to understand the successes and failures of German firms which have established production facilities and supplier networks in Shanghai and to elaborate on the role of culture

\footnotetext{
${ }^{2}$ We do not wish to imply, however, that the Shanghai automobile industry will develop into a fully-fledged cluster as more car producers move into other parts of China, possibly affecting the spatiality of the supplier networks in the long run.
} 
and institutions in this process. Between 2001 and 2003, five research trips were organized and more than 50 personal interviews conducted with representatives of automobile firms, their German and Chinese suppliers, as well as formal institutions which support the growth of the industry. Further, field study analysis was conducted in regular staff and strategy meetings and walking tours through the productions facilities of those firms investigated. In addition, exploratory interviews were conducted at the German sites of some of these firms.

This paper is organized as follows. In section 2, we develop a conceptual framework for the analysis of clusters which is build upon a multi-dimensional approach. This section also emphasizes missing links in the cluster literature, drawing on the importance of 'culture', institutions and power in network formation. In section 3, we focus on the genesis of the vertical and horizontal dimensions of the automobile industry cluster in Shanghai and the role of governmental authorities in this process. Section 4 deals with the consequences of 'cultural differences' between Chinese and German actors. Therein, we emphasize the role of boundary spanners - actors who have adapted their habits to the operational constraints and powers of the institutional context of the host country - and the process of institution building. In the final section, we summarize our findings and make some concluding remarks.

\section{Cluster dimensions in an inter-cultural context}

In this paper, we use the term cluster to refer to a local or regional concentration of industrial firms and their support infrastructure which are closely interrelated through traded and untraded interdependencies (Maskell 2001, Bathelt and Taylor 2002). Clusters can be analyzed along several dimensions; that is, their horizontal, vertical, institutional, external and power dimensions. Through this, different configurations of clusters can be identified according to their development stage and growth potential (Porter 1998, 2000, Malmberg and Maskell 2002, Bathelt 2002). Such a conceptualization may help to overcome some of the shortcomings and simplifications which Martin and Sunley (2003) have identified in much of 
the cluster literature. The institutional dimension is, for instance, largely neglected in Porter's (1990) work. Institutions are more or less treated as residual forces that are not important in the explanation of cluster phenomena and their continued growth (Bathelt and Depner 2003).

Here, we wish to emphasize another common problem in the literature on clusters which becomes particularly important in the context of international production arrangements - the tendency to under-conceptualize issues of power and culture. This is, in part, due to the fact that empirical studies focus on well-functioning clusters in particular regions. In such contexts, efficient communication processes between cluster actors already exist which enable reproduction within a homogeneous cultural and institutional environment. Such an environment does not, however, exist for firms establishing production linkages in a new country. Here, the existing cultural and institutional frameworks differ substantially between home and host country. The investors have to bridge these differences, establish efficient communication processes between agents with various cultural backgrounds and adjust organizational practices originating from the home country to those in the host country. In the following subsection, we wish to contribute to the development of an improved conceptual basis which particularly draws upon the cultural, institutional and power dimensions of a cluster.

\subsection{Cooperation and competition: the vertical and horizontal dimensions of a}

\section{cluster}

The vertical dimension of a cluster consists of firms with complementary products and competencies which are linked through supplier and customer relations. They benefit from intensive transactions within the cluster and form networks of traded interdependencies. It has been argued that an existing agglomeration of specialized producers creates an incentive for specialized suppliers and service firms to move close to these customers (Marshall 1920). The firms, in turn, benefit from low transportation and transactions costs, as well as economies of 
scale, and thus gain a competitive advantage (Scott 1988, Krugman 1991, 2000, Fujita, Krugman and Venables 1999). In part, this explains why existing clusters tend to grow, giving rise to labor market specialization.

But the advantages of clustering cannot be grasped by concepts of cost and traded interdependencies alone. In emphasizing localized capabilities (Maskell and Malmberg 1999a, 1999b) and untraded interdependencies (Storper 1995, 1997), recent studies have provided evidence that clusters offer manifold opportunities for inter-firm communication and interactive learning within the same socio-institutional and technological environment (Lundvall 1988, Gertler 1993, 1995). This generates specialized information flows and supports innovation (see, also, Cooke and Morgan 1998, Cooke 1999, Lawson 1999, Gordon and McCann 2000, Bathelt and Jentsch 2002).

In a similar way, advantages which result from a regional concentration of competing firms cannot be easily measured. Since the firms of this dimension produce the same sort of products and have similar competencies, they have little reason to cooperate with one another or engage in close interaction (Porter 1990, 1998, Maskell 2001, Malmberg and Maskell 2002). Co-location provides the opportunity to closely watch other firms and compare their economic performance with that of others (Maskell 2001, Grabher 2001). This is possible because firms in a cluster basically operate under the same conditions, sharing the same labor market, the same set of local suppliers and essentially the same cost structure. This creates a competitiveness to outperform others and serves as a strong incentive for product differentiation, process optimizing and cost reduction.

Co-location and face-to-face contacts within a cluster also give rise to additional advantages related to the circulation of information and inspiration (Bathelt, Malmberg and Maskell 2004). This creates a particular information and communication ecology in a cluster which has been labeled its 'noise' (Grabher 2002) or 'buzz' (Storper and Venables 2004). Already 
Marshall (1927) referred to something similar in his notion of 'industrial atmosphere' when pointing out that “... so great are the advantages ... from near neighborhood to one another. The mysteries of the trade become no mysteries; but are as it were in the air, and children learn many of them unconsciously." (Marshall 1920, 225). This buzz is related to constant flows of information and updates of this information, intended and unanticipated learning processes in organized and accidental meetings, based on the same understanding, interpretative schemes and technology attitudes within a particular value chain (Bathelt, Malmberg and Maskell 2004). The importance of this 'buzz' is that actors do not have to search their environment or make particular investments to get access to this information. They are automatically exposed to news reports, gossip, rumors and recommendations about technologies, markets and strategies by just 'being there' (Gertler 1995, Grabher 2002).

In the Shanghai automobile industry, we would also expect that this 'buzz' plays an important role. But, as will be shown in section 4 , information exchange between Chinese and German actors is often fairly problematic, indirect and incomplete, especially in the joint ventures.

\subsection{Trans-local linkages and the external cluster dimension}

Meanwhile, it is clear that a cluster cannot fully unfold its growth potential if the firms exclusively rely on internal markets and knowledge circulating through the local 'buzz'. If local linkages become too rigid and too exclusive, focussing on only a few local actors, this could cause problems of lock-in, gullibility and blind confidence (Granovetter 1973, Kern 1996, Oinas 1997, Scott 1998, Maillat 1998). This phenomenon of being too inward-looking, which has been described as 'over-embeddedness' (Uzzi 1997, Sofer and Schnell 2002), could cause firms to overlook technologies developed outside and slow down innovation.

Many studies provide evidence that decisive triggers for innovation result from trans-local partnerships with leading actors and firms from other regions (Bathelt and Taylor 2002). When firms consciously establish such 'pipelines' (Owen-Smith and Powell 2004) they can 
get access to knowledge pools and markets outside the cluster. As opposed to the local 'buzz', access to trans-local 'pipelines' does not happen spontaneously and participation is not free. It requires conscious efforts, substantial investments and is associated with a high degree of uncertainty (Bathelt, Malmberg and Maskell 2004). Partners in 'pipelines' must be carefully selected and trust has to be established, which is not a given (Lorenz 1999). Firms on both ends have to get to know one another and learn how to make joint adjustments and solve problems. If this works, local 'buzz' and trans-local 'pipelines' can be mutually reinforcing. The more firms engage in 'pipeline' development, the more additional information and knowledge enters the local 'buzz', driving product and process development. In turn, this knowledge enables firms to build up new ties to external actors (Bathelt, Malmberg and Maskell 2004).

In order to be able to make sense of trans-local knowledge flows, 'pipeline' partners have to develop a joint understanding. The case studies reviewed by Schoenberger (1999) and Dicken (2001) of multinational firms which have encountered difficulties when expanding their production networks to other countries and cultures exemplify this. An important pre-requisite for a firm to successfully establish 'pipelines' is the ability to assimilate the information arriving through pipelines and apply it successfully. Cohen and Levinthal (1990) have labeled this ability as being a firm's 'absorptive capacity' (Malecki 2000). This 'absorptive capacity' depends on the firm's direct interface with its local environment and on the number and extent of its 'pipelines'. It also depends on the way in which information can be transferred across and within sub-units of the firm. The role of internal gatekeepers and boundary spanners, which we will discuss further in the context of relational power, becomes crucial for translating externally produced knowledge into a form that can be internally understood (van den Bosch, Volberda and de Boer 1999, Giuliani 2002). 


\subsection{Culture and the institutional dimension in multinational production arrangements}

The ability to overcome barriers is most important in an international context where firms operate across national borders and cultural contexts. If firms are engaged in trans-local linkages with partners from other parts of the world, they have to be able to understand different institutional regimes in order to communicate and interact with their partners. This requires complex capabilities which are not that easy to achieve, as firms tap into particular cultures which can vary between places, regions and nations (Saxenian 1994, Gertler 2004). The debate about the 'cultural turn' in economic geography has shown that cultural contexts are an important influence on economic action which cannot be neglected (Crang 1997, Sayer 1997, Thrift 2000, Boeckler and Lindner 2000).

We are aware that it is quite difficult and problematic to define 'culture' (e.g. Lash and Urry 1994, Cavallardo 2001). There are many competing definitions and sometimes it appears that the term 'culture' is used as a catchphrase to include almost every human practice. It is not our intention to engage in this discussion. Rather, as Power $(2002,104 \mathrm{f})$ points out, "it is useful to stress that in contemporary capitalism culture seems to have particular characteristics that are constituted and bound into processes of definition and distinction that are inherently woven into the fabric of relations of production, consumption, and power that make up everyday life". Of great importance for the representation of culture are the implicit and explicit norms, rules, convictions, moral codes and philosophies of life which are accepted by or imposed on its members. These have developed through a history of social relations and are shaped, produced and reproduced in everyday's practices of human action and interaction (Lash and Urry 1994, Sayer 1997, Mitchell 2000, Hösle 2002). Language, arts, symbols, artifacts, etc. help create meaning and cultural identity different from that in other cultures. Through this, it is possible to distinguish 'insiders' from 'outsiders'. 
A cultural context creates an institutional framework for ongoing human interaction. At the same time, existing rules and norms are constantly being reshaped and new ones created through interaction. Therefore, culture cannot be reduced to a fixed number of characteristics. It is a fluid phenomenon, constantly in a state of flux. In this paper, we are interested in which way culture has an impact on human action and interaction in an economic context (see, also, Casson and Godley 2000, Porter 2002). ${ }^{3}$ Gertler (2004) points out that systematic influences of institutions, especially between different national environments, prevent the diffusion of universal operational standards or a single 'best practice' (see, also, Boyer 1998). As he states, "[t]he nation-state (whether 'home' or 'host') is still a primary source of influence over industrial practices" (Gertler 2001, 16). It seems to be a powerful umbrella for the use of not only language and the development of symbols and meanings associated with a 'culture'; it also stimulates particular ways of economic action and interaction through formal and informal institutions. It further shapes practices of learning (e.g. Tracey, Clark and Lawton Smith 2002). One way how these structures and practices are being reproduced is by the creation of social identities and 'othering' (Cavallardo 2001, Berndt 2003).

In general, the successful establishment of communication in a particular production configuration requires the development of a shared institutional context which enables interaction and knowledge creation. Conventions, accepted rules, norms, common standards, habits, shared heuristics and technology attitudes and other institutional arrangements are also

\footnotetext{
${ }^{3}$ This is not to say that culture is a homogenizing phenomenon. In relational economic geography (see Bathelt and Glückler 2003), culture is not a phenomenon which fully determines human action and interaction. It does create, however, patterns which are more or less accepted and have, over time, established structures and habits which make some actions appear more likely than others (Sayer 1997, Hodgson 2003). There is, nonetheless, always a fundamental openness as to, which way an individual may decide in a particular situation. When we talk about the views and habits of Chinese and German managers in this paper, we do not imply that such behavior can be put into simple categories.
} 
of great importance to enable inter-firm communication and collaboration in the context of a cluster (Amin and Thrift 1995, Maskell 2001, Bathelt 2002). A joint institutional framework enables specialized users and producers to discuss and solve problems (Hodgson 1988, North 1990). Such a framework does not, however, exist spontaneously. Through interactions between the actors of a cluster, joint problem-solving and experimentation lead to preliminary solutions, which must be robust in order to survive the next series of interactions. These solutions are constantly updated or adjusted to fulfill new goals in the innovation process (Storper 1997, McKelvey 1997) and thus become more specific over time.

The role of institutions becomes even more complex in a multinational production setting, where different rules of conduct exist which are not easy to grasp (Lundvall and Maskell 2000, Bathelt and Depner 2003). Actors are socialized in a particular societal context and adjust their habits in response to the existing specific institutional mix (Hall and Soskice 2001, Hodgson 2003). When German automobile suppliers, for instance, establish production facilities in Shanghai, this is done in an institutional surrounding which is largely unknown to these firms. Some of the institutions in the host country might also be incompatible with the practices of the investing companies which have, in turn, developed in accordance with institutional opportunities in their home country. To bring actors and institutions from different economic, societal and cultural contexts together is thus a difficult task. This is reflected by the numerous failures in multinational mergers and acquisitions in the past. Some hybridization of different production-institutional ensembles is likely to take place in such a situation, as has been shown in the case of Japanese automobile transplants (Abo 1996, Boyer 1998). In sum, car producers must introduce institutional settings to those existing in their home country or transfer elements of the specific production model to produce cars with equivalent characteristics and quality in the new country (Mair, Florida and Kenney 1988, Florida and Kenney 1991, Sadler 1994). 
In recent years, a new strand of literature has emerged which supports this view and emphasizes the durability of different national institutional settings. This work on 'varieties of capitalism' (Hall and Soskice 2001) and 'divergent capitalisms' or business systems (Whitley $1999,2000)$ is in opposition to other views which claim that different national models are converging. Interestingly, this work has some similarities with and complements earlier contributions of the regulation school (e.g. Lipietz 1987) and investigations into national systems of innovation (e.g. Lundvall and Maskell 2000). The 'varieties-of-capitalism' approach claims that the strategies, goals and structures of firms are deeply influenced by the institutional settings of the political economy in which they are embedded and vary accordingly. Hall and Soskice (2001) are especially interested in investigating those institutions which have an impact on the firms' strategic interactions. These are institutions which support the exchange of information, monitor the actions of others and enforce sanctions against deviating behavior. Particularly important are also 'deliberative institutions' which enable actors to engage in joint discussions and cooperation. The idea of this approach is that, due to social practices, institutional complementarities develop within a nation-state which create comparative advantages in certain activities and products. Similar to Lundvall and Maskell's (2000) argument, Hall and Soskice $(2001,38)$ emphasize that “... these advantages should give rise to cross-national patterns of specialization."

When firms establish production facilities abroad they often lack complementary institutions and find themselves in an economy which is fundamentally different. In the case of German car producers establishing joint ventures in Shanghai, the lack of 'deliberative institutions' which could provide a platform for exchange and joint strategy formulation between the joint venture partners is a severe problem. As argued in the next section, boundary spanners can become decisive in this context as they are able to bridge different mindsets. 


\subsection{Relational power and the role of inter-cultural boundary spanners}

A cluster does not automatically encompass a coherent group of firms which cooperate harmoniously with one another to achieve a common set of goals. The example of the Shanghai automobile industry cluster shows that a cluster's horizontal and vertical dimensions are shaped by existing power relations and asymmetries which impact the agents' ability to react to changes in their regulatory environment and external markets (Taylor 2000; Bathelt and Taylor 2002). But which mechanisms create consistent behavior within a cluster allowing participating firms and actors to act coherently and grow collectively? We would argue that a cluster can only then be considered as such if the internal actors, as well as those external to the cluster, recognize the cluster as an entity which is sufficiently different from its environment and act accordingly. In this case, clusters have causal power because network relations have an 'emergent effect' (Yeung 1994, J. Scott 2001, Dicken, Kelly, Olds and Yeung 2001); that is, they make the cluster visible to others. In actor-network theory, control over resources is not enough for an agent to become powerful (Latour 1986, Thrift 1996). In this view, those actors who are viewed to have power are able to build networks and develop them further by enrolling other actors (Murdoch 1995, Allen 1997, Smith 2003, Jöns 2003).

In a cluster context, it is not sufficient to focus on the power relations between two individual actors. Rather it is necessary to consider the whole structure of relations within the actornetwork. These social relations are constantly being produced and reproduced through ongoing communication between the actors, similar ways of solving problems, joint decisions about which technologies to use and the like. This is not a simple diffusion of information from one end of the cluster to the other. Rather, this should be viewed as a translation process where messages are being transferred to other actors through social relations who evaluate them according to their goals. During this transfer, the messages are constantly being interpreted and reinterpreted by those actors involved, giving each actor the opportunity to 
change it (Latour 1986). The power of a cluster can thus be defined as the potential to enroll cluster firms in joint enterprises. ${ }^{4}$

Of course, it is difficult to establish coherence within a cluster through social relations alone. Material and non-material resources, such as non-human artifacts (e.g. particular technologies, symbols), tools (e.g. manuals, reports) and accepted rules, enable human actors to engage in social relations and keep them going (Murdoch 1995). They are the glue of social relations (Latour 1986). In a cluster, particular process and communication technologies serve to stabilize interactions between the firms, as they have similar day-to-day experiences and develop the same understanding. Especially, in an inter-cultural context, such as in the Shanghai automobile industry cluster, shared technologies and existing norms and rules are important to support the interaction between people from different contexts in achieving common goals. Material and non-material resources clearly help shape the course of action. Without them, messages could, for instance, be easily misinterpreted by other actors and technologies used inappropriately.

Since the coherence of a cluster and its ability to work are dependent on day-to-day interactions between its actors and firms, distance and visibility are of great importance. They enable ongoing interaction with others through a multitude of micro-practices and to exercise control over their activities. The question which arises from this is how social relations can be maintained if the actors do not have regular contact. In fact, it is not an easy task to exercise

\footnotetext{
${ }^{4}$ This includes the capability to make joint decisions and collectively solve problems which occur in the course of action. Power as relationships creates a particular sort of hierarchy and rules of dominance and subordination within a cluster network (Allen 1997). Emerging power asymmetries are produced and temporarily stabilized through circuits of power (Clegg 1989, Taylor 1995). They are fluid and always changing, yet capable of reproducing the cluster unless existing inequalities are no longer being accepted. In this case, power struggles would be the consequence, threatening the coherence of the cluster (Bathelt and Taylor 2002).
} 
power over distance (Murdoch 1995, Allen 1997). This requires the introduction of effective technologies and routines, enabling actors to check the outcomes of their orders which occur in different places. In the words of Dicken, Kelly, Olds and Yeung $(2001,104)$ " [t]he ability of actors to reach across space and act at a distance ultimately depends upon entraining other actors and the necessary material objects, codes, procedural frameworks and so on that are required to effect the activation of power." This is, of course, a key issue in the relation between the headquarter locations of German firms and their Shanghai branches.

According to this relational view of power (Glückler and Bathelt 2003), network builders who are able to enroll others into networks are particularly important in the process of network activation and formation. In an inter-cultural context, the role of boundary spanners also becomes important as they have the potential to communicate between the people involved and provide an understanding of heterogeneous habits and attitudes. Coe and Bunnell (2003) emphasize the importance of transnational communities in translating news, claims and problems back and forth between the different nationalities and parties in an inter-cultural production setting (see, also, Hsu and Saxenian 2000, Smith 2003). These are people who have lived and worked in different cultural contexts and are able to understand the different expectations and patterns of behavior and clarify them between actors. They are not to be confused with traditional immigrants as they develop professional expertise and maintain active contacts with both their home and host cultures. Saxenian and Hsu (2001: 915f.) conclude from their case study of US-Taiwanese linkages in high-technology industries that "[a] transnational technical community allows distant producers to specialize and collaborate to upgrade their capabilities, particularly when the collaborations require close communication and joint problem-solving. The trust and local knowledge that exist within technical communities, even those that span continents, provide a competitive advantage ...”. 
In the context of a multinational production arrangement, such as the Shanghai automobile industry cluster studied in this paper, boundary spanners can be extremely valuable in communicating between managers and workers from different cultural contexts. Our argument is that many inefficiencies and problems could be avoided if knowledgeable intercultural boundary spanners would be employed by German firms entering the Chinese market. Within joint venture firms, these boundary spanners could help stimulate shared systems of meaning and allow access to inter-cultural knowledge pools. The conceptual framework developed in section 2, which draws particularly on the consequences of a multinational or inter-cultural setting upon the institutional and power dimensions of a cluster, serves as a basis to analyze the establishment of a new automobile industry cluster in Shanghai. In section 3 and 4, we investigate how this cluster has been initiated and shaped by political influences and analyze the cluster along its dimensions.

\section{Genesis and growth of the automobile industry cluster in}

\section{Shanghai}

Shanghai has a long industrial tradition. Before the People's Republic of China was founded in 1949 , the city was already a major industrial center, characterized by lighter manufacturing such as the production of textiles, cigarettes, leather and rubber goods. Later on, to fulfill Mao Zedong's development targets, the Chinese government restructured the economy and established heavy industries, such as the chemical and steel industry (Mok 1996). When China undertook its first steps to open the economy by designating 'special economic zones' and 'open cities' and directing foreign investment to these areas Shanghai was not included. This was due to the fact that the city was regarded as the central industrial core in the country and, as such should not be part of economic experiments. In the early 1990s, the government regretted this decision and opened the city for foreign investors. The automotive industry was selected as one of a total of five 'pillar industries' to shape the future development. After the 
financial crisis in Asia, the municipal government strengthened its support of the city's manufacturing sector and postponed plans to focus particularly on the financial and trade sector (Zeng 2000).

\subsection{The role of SAIC as a nucleus of the cluster}

The Shanghai Automotive Industrial Corporation (SAIC) is the dominant Chinese player in the Shanghai automotive industry (Figure 1). As the group is largely state-owned, with the majority of its shares being controlled by the city of Shanghai, SAIC is closely interlinked with and supported by the city's policy makers. It is more, however, than a remnant of the old era of state monopoly. The SAIC group consists of different companies and establishments, which manufacture cars, trucks, busses and motorcycles, as well as parts and equipment. ${ }^{5}$ By the end of 2001, SAIC had established 55 joint ventures with other automobile and component manufacturers and employed almost 62,000 people (SAIC 2002).

SAIC is one of three domestic car producers which have strong governmental support in order to reduce inefficiencies in production and become competitive at an international level (China Business Update 2001). The operations of SAIC are not limited to Shanghai, as the group continuous to grow and expand through, for example, state-owned property transfers. In 2001, it acquired 75,9 \% of the shares of Liuzhou Wuling Automotive Co. (SAIC 2002), through which a second joint venture with GM with a 50,1\% stake was formed only a year later. Until

\footnotetext{
${ }^{5}$ Until 2000, all Chinese automobile firms were state-owned enterprises, yet under the control of different authorities. The two most important enterprises, i.e. First Automotive Works (FAW) in Changchun and Second Automotive Works (SAW; later renamed into Dongfeng) in Central China, were under direct control of the central government in Beijing. In the 1960s, additional automobile enterprises were established and controlled by those provinces which had set them up. Since each of the car producers had its own supplier network, several such networks developed parallel to one another without much overlap and interaction (Lee 2001, Sit and Liu
} 2000). 
2003, SAIC also held shares of the domestic joint venture SAIC-Chery Automobile Co., but had to give these up because of complaints of VW and GM that unintended technology transfers took place through Chery.

An automobile cluster began to develop in Shanghai since the 1980's thanks to great governmental support at different levels. In the beginning, the central government's initiative was key in attracting VW to China. In order to upgrade the national automobile industry to meet international standards and to avoid having to import automobiles at a large scale, the central government started negotiations with Volkswagen (VW) in $1978 .{ }^{6}$ These resulted in a joint venture agreement between SAIC, the Bank of China, China National Automotive Industrial Corporation (the parent organization of the Chinese automobile industry) and VW. This joint venture, which was called Shanghai Volkswagen (SVW), started production of the 'VW Santana' in 1985.

Later on, the development of the automobile industry in the city was very much supported by policies of the municipal authorities, such as infrastructure development, labor market and industrial policies (e.g. Harwit 1992, Zeng 2000). In addition, the central government enforced local-content regulations upon VW in order to spur the development of a regional production network with substantial local linkages. The idea behind this policy was to stimulate broad manufacturing competencies within the region and integrate Chinese suppliers, instead of importing key supplies from abroad. As a consequence, SVW demanded that its first-tier suppliers establish production facilities in China, preferably within the region. Through this, the vertical cluster dimension developed quite rapidly. The resulting supplier

\footnotetext{
${ }^{6}$ In that year, the country's state-owned industry produced only 15,500 automobiles. The industry was characterized by old-fashioned, low-quality cars which were produced with outdated equipment in laborintensive processes (Yang 1995, Kiefer 1998).
} 
network is one of the most advanced in China (Yang 1995). Shanghai and its neighboring provinces also have the largest agglomeration of parts makers in China (KPMG 2003).

Originally, VW had decided to set up production in Shanghai mainly for strategic reasons, not only to develop a core from which to access the Chinese market but also to have a gateway to other East Asian markets (Richter and Vettel 1996, Kiefer 1998, Lee 2001). In the initial years after production was launched, SVW still imported most parts and components for the production of the VW Santana from overseas, a large part of which was from Germany. At that time, there were basically no firms within the region who could have supplied the parts needed. In the late 1980s, the Chinese government threatened to enforce a production limit upon SVW if the firm would not increase its local content in production. Zhu Rongji, at that time an influential politician in Shanghai, was especially interested in supporting the growth of the automobile industry and mediated between the central government and SVW (Harwit 1992). Later, when he had become mayor, he was responsible for implementing the policy that each taxi in the city had to be a VW Santana (Sit and Liu 2000). This, of course, served to jump-start the local automobile industry, i.e. SVW.

In the 1980s, the number of VW Santanas produced in Shanghai was too small for VW's German suppliers to establish production facilities in China. In 1990, SVW still assembled less than 20,000 cars per year (Table 1). In order to fulfill the local-content regulations of the central authorities, SVW began to enroll Chinese parts producers to join the 'Shanghai Santana Local Content Cooperative'. The municipality supported this initiative by increasing the prices of cars by $16 \%$ and provided low-interest loans to the local suppliers (Lee, Chen and Fujimoto 1996). By 1991, many of the parts producers, which were originally controlled by different authorities, had become integrated into the SAIC group.

Still, this was not enough for SVW to establish an extensive local supplier network similar to the way it operated in Germany. Since the 1980s, there has been a strong tendency in the 
international automobile industry to develop hierarchical supplier networks and shift development, manufacturing and assembly responsibilities of important modules to the first tier of suppliers. This reorganization led to intensified collaboration in the production chain and enabled the car producers to reduce the number of direct suppliers substantially (Sadler 1994, Schamp 1995). Along with the globalization strategies of the automobile producers, first-tier suppliers were also increasingly required to follow their clients to other countries when these established new foreign production facilities (Humphrey and Memedovic 2003, Depner and Dewald 2004). This policy had significant consequences for the Shanghai automobile industry. While there were only nine foreign suppliers with local operations in 1993 (Yang 1995), this number increased quickly in the subsequent years. Especially, firsttier suppliers from Germany began to set up facilities in Shanghai (Figure 2).

\subsection{The SAIC joint ventures: triggering vertical and horizontal growth}

The majority of German suppliers chose to enter the Chinese market by establishing a joint venture with one of the subsidiaries of SAIC but this was not always a decision of free will (Depner and Dewald 2004). In some instances, SAIC demanded that those firms entering the supplier network of SVW establish German-Chinese joint ventures and set up their facilities in Shanghai. SAIC's strategy in this process was obviously to integrate as many suppliers as possible into its own group network in order to develop broad competencies in the production of automobiles. Eventually, this would enable the SAIC group to produce cars on their own. Joint ventures between German suppliers and SAIC seem to offer advantages to both sides. SAIC benefits from the technology transfer which takes place. The German firms are able to use existing production facilities, acquire parts and components through established channels and have access to partners of SAIC, including other automobile producers. As will be shown later, day-to-day interactions between the German suppliers and their joint venture partners can, however, be very complicated and inefficient. As a result, some German firms went a 
different route and set up wholly foreign-owned enterprises (WFOEs) or established a joint venture with a non-SAIC firm. This was not without risk, however. One Sino-German joint venture studied, which was established without the participation of SAIC, ran into difficulties, as it had to undergo unusually hard, uncooperative audits by a SAIC subsidiary which the manager of that firm referred to as 'inquisition' (Interview 17). Other managers in similar situations mentioned that they were under much greater pressure to cut costs than their SAIC counterparts (Interviews 18, 31).

Until 2001, most German suppliers were able to make profits through their Shanghai operations despite the relatively small number of units they produced. Some of the SAICGerman joint ventures reached their break-even already during the first year of production. In recent years, however, competition has increased and price control lifted, creating pressure on the automobile producers to reduce car prices. ${ }^{7}$ One interviewee mentioned that, as a consequence, SVW demanded its suppliers to cut cost by 10-40 \% in 2002 (Interview 35). This price pressure serves as an incentive for the suppliers to build up a local base for their parts production instead of importing parts and components at high costs.

At the same time, the establishment of local parts production is also time-consuming and requires substantial investments. Often there is no alternative, however. Although there are approximately 5,500 suppliers in China (Roland Berger Consultants 2001), it is very difficult to find high-quality, technologically sophisticated firms which the German suppliers can rely on. Several managers blamed Chinese firms for claiming that they are able to produce parts according to the specifications needed even though they were not able to meet their standards

\footnotetext{
${ }^{7}$ The year 2001 was a milestone for the Chinese automobile industry, as the country joined the WTO. As a prerequisite for this, customs-duties for imports had to be reduced and import quotas increased, thus allowing for higher competition from the world market. In addition, price controls were lifted by the central government.
} 
(Interviews 1, 3, 14, 15). Several interviewees also criticized the low quality of those parts produced by Chinese suppliers (Interviews 22, 30, 42, 52). Therefore, it is an important task for German firms to find reliable Chinese suppliers and conduct knowledge transfers to upgrade the organizational and technological capabilities of these firms. This requires many meetings between staff members of both firms and visits at the plants of the Chinese suppliers. To enforce quality standards, some German firms have begun to make surprise visits at their suppliers' plants to check up on quality. To do this, of course, requires that the Chinese suppliers are 'visible' and located close-by. ${ }^{8}$

Despite these problems in producer-user relations, the policy to increase local-content production has generated a growing vertical dimension of the automobile industry cluster (Figure 3). In 2002, SVW had 371 suppliers that were located in China. The local content in the production of cars ranged from $40 \%$ for the newly introduced VW Polo to $93 \%$ for the VW Santana (Depner 2003). ${ }^{9}$ Supposedly, the existing supplier network and industrial infrastructure were important reasons as to why GM also decided to set up production facilities in Pudong in 1997. Consequently, Shanghai General Motors (SGM), a joint venture

\footnotetext{
${ }^{8}$ As one manager pointed out, some firms do not even try to integrate Chinese parts producers but, instead, continue to rely on imports or purchase parts from internationally renown suppliers with Chinese operations (Interview 17). Another interviewee explained that his firm did not intend to expand local supplier linkages further as they had already reached a certain level. He was fed up with the process of establishing links with Chinese suppliers, as this would require too much attention and manpower (Interview 46). Even a Chinese executive complained about the Chinese suppliers: "They don't have the management capabilities, they have no capital and no technologies. I don't want to work together with these companies any more.” (Interview 34).

${ }^{9}$ Caution should be exercised, however, in using these numbers of local-content production. The actual share of parts being produced locally is likely to be lower as the German suppliers still import many parts and components from within their corporate networks. The resulting products from such practices are then classified as being 'Made in China'.
} 
between GM and SAIC, tapped into the supplier network of SVW. By 2002, almost all of the German suppliers investigated sold parts to SGM, although SVW was their major customer.

Prior to 1997, SVW was the only car producer in Shanghai having thus developed an exclusive network of suppliers. For a long time period, the firm produced only one model, i.e. the VW Santana, for the Chinese market. ${ }^{10}$ To reduce its dependence on VW and to put pressure that it changes its product policy and increases technology transfer, SAIC decided to engage in a joint venture with GM. Since its establishment, SGM has grown into one of the large car producers in China. Between 2001 and 2003, GM increased its market share in China substantially from $2.7 \%$ to $9.9 \%$, mainly due to its Shanghai operations (Vwd: Asien 2003a, Automotive Resources Asia 2004). Due to the activities of SVW and SGM, Shanghai accounted for $40 \%$ of the overall car production in China in 2001 (KPMG 2003).

GM's entry into the Chinese market and its cooperation with VW's joint venture partner SAIC has also initiated a number of changes in the product strategy of SVW. The firm now produces different models in Shanghai, i.e. the 'Santana', 'Santana 2000' (a model which was originally customized for the Brazilian and Chinese market), 'Passat' (since 2000) and 'Polo' (since 2001). In 2002, SVW started to produce the 'Gol' in Shanghai, a model which was originally designed for Brazil. One interviewee pointed out that VW now pushes the establishment of broad engineering competencies in Shanghai to be able to adapt cars to the specificities of the Chinese market (Interview 51).

SAIC has benefited from close relationships with VW and GM. Until 2002, SAIC was also involved in the national joint venture SAIC-Chery Automobile Company (Table 1). This joint

\footnotetext{
${ }^{10}$ Another joint venture of VW and FAW in Changchun, which was established in 1991, developed its own focal supplier network in the Changchun region. German suppliers which wanted to do business with both operations of VW had to invest into two separate joint ventures, i.e. one with FAW and one with SAIC.
} 
venture integrated components of SVW's German-Chinese suppliers which had initially been developed in Germany for VW. This created severe conflicts as VW Germany regarded the parts and components as its intellectual property and did not agree with SAIC's move. According to two executives, the headquarters of the suppliers in Germany were asked to stop deliveries to SAIC-Chery. Otherwise, they would have to suffer negative consequences in their supplier relationships with VW (Interviews 8,24). The suppliers in Shanghai did not agree with this policy as they benefited from additional production in terms of the exploitation of economies of scale. Nonetheless, they had to follow VW's decisions in order to avoid further problems. Later on, SAIC-Chery also copied two GM models. After investigations and accusations of GM, SAIC had to sell its stakes in this joint venture in 2003 (Tierney 2003). Other conflicts between the foreign car producers and SAIC seem, however, to be merely a question of time, as SAIC has announced to build cars entirely on its own in the future through its publicly listed subsidiary Shanghai Automotive Co. (Vwd: Asien 2004).

At present, SAIC's dominant position in the Shanghai automobile industry remains unchallenged. Due to its close ties to local authorities, banks and China's federal government, the group is capable of exercising power over the course of the entire automobile industry cluster. SAIC has benefited from the competition between SVW and SGM by taking over much of their technologies and developing stronger manufacturing competencies. Being involved in several joint ventures also enables the firm to play one partner off against another and shift resources accordingly. On one occasion, Chinese personnel that was originally trained by SVW was transferred to SGM. This does not exactly provide grounds for the establishment of trust between the joint venture partners. Skepticism also increases because SAIC moves managers from one joint venture to the next throughout the course of their career. These executives are not able to develop strong relationships in any joint venture operation, as they know that their jobs are only temporary. This rotation system is not in the interest of the 
German joint venture partners because it might create stronger information flows between than within the SAIC joint ventures.

\subsection{Intra-company ties: providing access to technologies developed outside}

The ties between German headquarters and their subsidiaries in Shanghai are still very strong but appear to be in a state of flux (Figure 3). Until fairly recently, SVW produced just one car model, supported by a network of exclusive suppliers. The Shanghai operations were highly dependent on the decisions made at the German headquarters, as the statement of an executive of a German supplier to SVW exemplifies: "We do not have to think, we only have to produce. ... We are a prolonged work-bench and have no freedom at all." (Interview 15). VW's engineering and development activities are still concentrated at its headquarters in Germany, with the exception of those models which have been designed for foreign markets, such as the VW Santana 2000 and VW Gol. Upgrading and engineering activities of other models which are also produced in Europe, such as the VW Passat and VW Polo, tend to be focussed at the firm's headquarter location. Only minor adaptations to Chinese market requirements have, thus far, been designed in Shanghai. When the German headquarters of VW decide to make changes to a model, the respective suppliers are contacted by the German headquarters. This rigid hierarchical structure is changing, however. As the suppliers diversify their customer base in China, their development and engineering competencies within the country need to be furthered. To achieve this, some suppliers have begun to set up engineering departments in Shanghai (Interviews 33, 45, Case study 2). An executive of a German-Chinese joint venture pointed out that this was absolutely decisive. Technicians of a Chinese car producer had come to him one day for help in the construction of a particular module. As they were unable to explain the problem in technical terms, they simply presented a copy of a similar module to him (Interview 35). To respond to such a request for help requires their engineering competencies be available. 
Linkages between operations in Germany and China are not restricted to the communication of technical instructions. In the case of joint ventures, for instance, ties to Germany are also activated through regular board meetings which provide a means to monitor the performance of the Chinese operations and develop strategies for future activities. Exchange also takes place in both directions, as management and technical personnel are sent from the headquarters to foreign locations for a few years. Most German executives in Shanghai have a three-year contract which can normally be extended. An obvious goal behind this strategy of constantly employing executives, managers and technicians from Germany abroad is to maintain control over the production activities in China. While some firms have a substantial number of Germans who have worked at their Shanghai locations over a longer period of time, others attempt to limit the stay of their employees. Often, they replace German managers by Chinese experts who have studied or lived in Germany and have acquired knowledge of both production contexts. In such firms, German experts are usually appointed to work at the Shanghai facilities for shorter time periods, often associated with the solution of a particular problem or the introduction of technological and organizational innovations (Interviews 14, $23,45,47){ }^{11}$

Further, Chinese managers and technicians are also sent to Germany for training purposes and to obtain work experience. This appears to be an efficient way to train them and make them familiar with German routines, as has been pointed out by some German executives (Interviews 27, 48). The advantage of training qualified Chinese employees abroad is that

\footnotetext{
${ }^{11}$ Another important link to firms in other countries results from the need to install and run specialized machinery and equipment in the production process. Most of these machines are not produced in Shanghai or other Chinese regions, as the machinery industry in China is still in an infant stage. German firms also prefer to use the same type of machines at different locations and to cooperate with those machinery suppliers they already know from Germany (Depner and Dewald 2004).
} 
they are removed from their day-to-day working context where they could be watched and evaluated by their co-employees.

Over time, the Shanghai operations of German automobile suppliers have been able to reduce their dependence on their headquarters and make more decisions about daily practices and local market strategies on their own. This occurs as Germans are increasingly being replaced by Chinese managers and producer-user linkages become more diversified, due to a growing horizontal and vertical dimension of the cluster. Experience has also shown that it is quite difficult to make all decisions about the course of operations over such a distance and from another cultural and institutional context.

\section{Difficulties of establishing cooperation between Chinese and German actors: issues of culture and power}

Having analyzed the development of the vertical and horizontal dimensions of the Shanghai automobile industry cluster and its close linkages to and dependencies upon the German headquarters of the respective firms, we will now focus on the effects of culture, institutions and power. These are somewhat neglected in standard textbooks, although they are at the core of the success of those firms which operate in a multinational, inter-cultural environment. In this section, we investigate how formal institutions are being imported to and new institutions created in the Shanghai automobile industry. Further, we discuss the intra-firm problems which arise from different norms, habits and expectations between the German and Chinese management and workforce of the joint ventures. We argue that boundary spanners can become decisive in overcoming such problems, mediating between individuals with different opinions and views in an inter-cultural context. 


\subsection{Crossing the 'cultural barrier': different tastes, expectations and behavior}

The transfer of production arrangements and industrial practices to another national institutional context requires adaptation to the social and economic structures of the host country (Abo 1996, Boyer 1998). Hybridization takes place as firms redesign products to fit the tastes and specificities particular to a national market and adjust their day-to-day routines and division of labor to the conditions at hand. In addition, the establishment of a joint venture requires that a viable management system be developed which is capable of solving the problems and tensions which originate from the different institutional contexts of the joint venture partners. This is in fact a difficult task which can easily result in failure. This is exemplified by a number of the joint ventures studied, where either the German or Chinese part of management had to be replaced due to severe problems in communication and interaction.

Successful adaptation to another cultural context requires that German firms adjust their products, at least to some extent, to meet the customers' tastes and behaviors of the new market. SVW, for instance, had to make its Passat model longer in order to fit Chinese tastes. Compared to product adjustments, however, adapting to a different way of doing business in another institutional context is even more difficult. From our investigation, it seems that many German firms underestimate the challenges they face when they extend their business to another political, cultural and economic setting. They seem convinced of their technological capabilities and the superiority of their products. In following their 'missions', they believe they can simply transfer their rationality and bureaucracy to the Chinese context. HoonHalbauer's (1999) survey has revealed, however, that German managers in Shanghai had only a limited knowledge of the peculiarities of the Chinese context.

One important aspect, which cannot be ignored, is that the Communist Party (CP) still has a strong influence on economic structures and processes in China. Larger joint ventures, for 
instance, all have an extra CP office. According to Hoon-Halbauer (1999), CP secretaries are the main decision-makers on the Chinese side, especially in the large joint ventures. German executives mentioned that it is virtually impossible to change the internal organization of a joint venture and shift personnel from one position to another if the $\mathrm{CP}$ does not agree with these changes. It also seems difficult to fire a worker for whatever reason if he/she is a member of the CP (Case studies 2, 4). When CP meetings are announced, they have a high priority for the Chinese workforce. If this conflicts with other meetings, even those that have been scheduled much earlier, they typically must be cancelled in favor of the CP meeting. Influenced by the $\mathrm{CP}$, some Chinese managers view a joint venture not just in terms of its business goals, but also see it as part of a larger picture supporting the overall growth of the Chinese economy (see, also, Zhu, Speece and So 1998).

Another important aspect of the Chinese societal context is that communication within and between firms is often based on personal relationships. Actors engage in the formation of dyadic relationships called 'guanxi', which are based on joint interest, interdependence, reciprocity, trust and open-endedness. Such relationships are quite stable and long-term in character and are associated with particular obligations and benefits for each side (Hsu and Saxenian 2000, Yeung 2000, Wang 2001). ${ }^{12}$ Engagement in these 'guanxi' is shown through regular contacts and reciprocal confirmations between those parties involved. The consequence of this reliance on 'guanxi' in the social organization of production is that Chinese managers invest a lot more time into the maintenance of these relationships and

\footnotetext{
12 'Guanxi' define rules as to how a person should act in certain situations, depending on the type of relation he/she has with another person. In a society which is based on clear rules and commitments according to the structure of social relations, the law system and contracts do not play an important role. This is, however, problematic for foreign companies to grasp as they are used to relying on the authority of contract and law, instead of more-or-less tacit, unwritten rules and regulations.
} 
spend less time for strategic planning and administrative duties than do their European and American counterparts. 'Guanxi' obligations and returns can also be passed on to third parties.

A Chinese manager who has established 'guanxi' with two formerly separate parties, for instance, can bring these together to form a larger network ('guanxi wang') (Hwang 1987, Björkman and Kock 1995).

The Chinese executive of one firm which relies mostly on local Chinese suppliers stated that a German could not do his job very well because he/she would not know how to establish and maintain personal relationships with managers of the suppliers. He described that these relationships went beyond the pure economic (Interview 29). This statement may, however, underestimate the possibility of foreign individuals to obtain access to Chinese networks. In some cases, German managers mentioned that they were able to establish close ties with some of their Chinese co-workers, customers or suppliers, which helped them improve interaction (Interviews 5, 20, 36, Case study 3).

\subsection{Import and creation of institutions}

Despite the attempts of the Shanghai municipal authorities to establish a business climate which encourages foreign direct investment, the different institutional context of China provides a substantial barrier for those German firms who have no experience of operating in this context. A lack of knowledge regarding the political, cultural and societal setting causes problems when dealing with Chinese authorities, customers, employees and the like.

In order to provide support for German firms investing in Shanghai, the 'German Chamber of Industry and Trade' and 'German Chamber of Foreign Trade' have jointly established the 'Delegation of German Industry and Commerce in Shanghai' (GIC). This organization employs 60 experts to help German firms make their first steps in this institutional context. They give advice on how to set up production facilities, how to get approvals from Chinese authorities and how to find Chinese suppliers (Interview 13). GIC also organizes cultural 
events and regular meetings for German technicians and managers working in Shanghai where they can obtain information about new governmental regulations and market trends. Such meetings also provide opportunities for the exchange of information about problems and experiences with other Germans. There are even regular meetings for executives of automobile firms and their suppliers. Such meetings are important in providing social contacts within the automobile industry cluster in Shanghai, which are otherwise not very common. But the 'buzz' between the German experts is not very intense; in several interviews conducted, executives mentioned that they were not overly interested in having intensive contact with other Germans outside their respective firms. They work extremely long hours and, thus, do not have the time nor interest for additional meetings (Interviews 16, 22, 27). One of the problems of the Shanghai automobile industry cluster is that the local labor market, which has expanded rapidly in conjunction with the growth of the industry, has not been able to satisfy the demand for specialized workers. Firms seemingly have difficulties finding suitable personnel and consequently compete with one another for skilled workers. One executive reported that the Chinese workforce is quite mobile. Some engineers would even leave their workplace if a competitor would offer an increase in their monthly salary of a mere RMB 200 (US-\$25) (Interview 1). Because of the shortages on the labor market, German firms and organizations have begun to improve the vocational and professional training system in Shanghai. The 'Hans Seidel Stiftung' (a political foundation based in Bavaria), for instance, opened a vocational training center in which skilled workers of more than 100 firms are being trained. At Tongji University, a Chinese-German university college was founded in 1998 where Chinese students can obtain specialized skills and receive degrees required in the industry. German universities, such as those in Bochum and Munich, participate in professional training programs by sending staff for temporary teaching positions. German automobile firms support such initiatives. SVW and its German supplier Bosch, for instance, have provided funds for additional chairs at Tongji University. 
In order to ensure high quality throughout the local production chain, German investors forced German or American quality management systems onto their suppliers in the late 1990's (Hengenberg 1999). One of the largest German organizations for the control of technical and management systems in industrial firms, i.e. the 'TÜV Rheinland-Brandenburg', has, for instance, established several branches in China. According to an executive of this organization, the vast majority of first- and second-tier suppliers in Shanghai are already certified according to the VDA 6.1 and QS 9000 standards of the German and American automobile industry associations, respectively (Interview 39). Automobile producers demand these certificates from their suppliers, although they also conduct their own supplier audits as well. As Chinese organizations have also been founded which grant similar certificates, this has become complicated. These certificates do not seem to have the same value, however, as those granted by their German counterparts. Some German managers complained about these certificates because the auditors are seemingly sloppy in their work (Interviews 16, 19, Case studies 2, 4).

\subsection{Intra-firm tensions and potential communication failure}

Theoretically, multinational joint ventures have a great potential to overcome inter-cultural barriers and stimulate knowledge creation and interactive learning. In reality, this is not necessarily a given thouh as it first requires that a common set of rules and routines be established and supported by all parties (Boyer 1998). Problems exist because Chinese and German actors and firms are embedded in different sets of institutions from different cultural contexts which may not be fully compatible. It appears that mistrust, allegiance, lack of communication and conflicting conceptions are major problems in the day-to-day operations of joint ventures (Hoon-Halbauer 1999), which arise from the embeddedness of the involved actors in different societal contexts. 
Therefore, the establishment of efficient management systems between the German and Chinese partners in joint ventures seems to be an arduous task. According to Hoon-Halbauer (1999), Chinese executives in joint ventures often regard the transfer of management knowhow as a change in their traditional 'organizational culture'. This can become a major root of conflict within a joint venture. Executives at the German headquarters can also be quite skeptical and distrustful of their Chinese counterparts, which provides another barrier for communication. Kiefer (1998) argues that the performance of SVW would have been better if the German management had attempted to integrate the Chinese 'guanxi' system into its organizational structure, instead of pushing a hierarchical Taylorist division of labor. According to him, things went better when Germans did not try to intervene.

The circulation and diffusion of information provides a good example of the differences which exist between German and Chinese organizational routines. In German firms, it is normal to have regular business meetings in which managers are expected to scrutinize the performance of their divisions and make suggestions regarding future activities. This seems unusual in the Chinese context. In the meetings where we participated, decisions were hardly ever made. The Chinese managers did not seem to really listen to what was being said (Case studies 2,4$)$. In fact, they used their mobile phones, smoked cigarettes, talked to their neighbors and even periodically left the conference room during meetings. The Chinese managers obviously did not regard these meetings as the 'right' setting to make decisions. Hardly any of the Chinese managers participated actively in the discussions, except for the executive manager. This pattern changed only when issues were raised which were directly related to the Chinese personnel of the firm. As a consequence of these meetings, the German management was dissatisfied with the results, as, from a German view, there did not seem to be any decisions made. It seemed that information transfers between Chinese managers were more likely in small groups in less formal surroundings. This could, in part, be explained in terms of the concept of 'face', which is still important in the Chinese society. According to 
this, the status of an individual within a group depends on the respect he/she receives from other members of the group (Hwang 1987). A person can loose 'face' if he/she is unable or unwilling to fulfill certain tasks and commitments to the group. Since this would cause social isolation, Chinese workers are unlikely to admit failures openly or criticize others in public. It appears that German firms often send executives to their Chinese operations who are primarily technical experts but lacking knowledge on how to manage a company successfully in an inter-cultural context. Sometimes those managers know surprisingly little about the expectations and patterns of behavior of Chinese workers and managers. As a result, they can easily misinterpret or misunderstand the actions of their Chinese counterparts. Other studies confirm our findings that Chinese managers in joint ventures are unsatisfied with their position and how they are often treated (Zhu, Speece and So 1998, Hoon-Halbauer 1999). Some indicated that their experience was not respected very highly by their joint venture partners. They also complained about the arrogance of their German counterparts. One Chinese interviewee stated that "[i]n China market economy means friends economy. ... you need experience not muscle!" He pointed out that German managers who come to China are often too young and do not stay long enough to understand what is going on (Interview 19). In comparing two German managers whom he knew really well, another Chinese interviewee said that the one who fits better in the Chinese context compared to the other would gain more respect by Chinese people because he made a conscious effort to listen to the people, tried to avoid conflicts and had strict principles. The other manager, he admitted, had better management skills, regarded from a western perspective, but was not as effective in mobilizing the joint venture staff as the first manager (Interview 15). In this case, one could say that the first manager is more 'powerful' in the sense of Latour (1986), being able to mobilize people in an inter-cultural context (see, also, Murdoch 1995). 
In joint ventures, it is the German parent who either nominates the general or the deputy general manager. By contract, both sides are usually expected to agree upon important decisions before they are implemented. But this is often not the case in reality. Decisions are made by one side without informing the other or they are dragged out (Interviews 15, 18, 33, Case studies 2, 3, 4). Problems particularly arise when decisions have to be made about which machinery to buy, which customers to do business with and whether certain parts of production should be outsourced. The conflicts which arise in such situations are an important source of distrust within the joint ventures. German executives sometimes do not know where their Chinese counterparts are and in what kind of external meetings (i.e. within the SAIC group) they participate and why. One interviewee mentioned that his Chinese deputy manager would sometimes stay away from the firm for a couple of days without telling anybody where he is (Case study 3 ).

Problems also arise between a firm's German management and its Chinese workers. It is, for instance, difficult to persuade the workers that production routines need to be changed if the Chinese management does not clearly support this. It seems that their allegiance towards Chinese superiors is greater than that towards the German ones (Case studies 2, 4). One German interviewee thought that this was natural. If the Chinese workers would lean too much towards the German management, the consequences could be negative as they would be on their own once the Germans eventually return to their headquarters (Interview 33). Severe problems can also arise when German managers lose their temper in front of Chinese coworkers. According to the concept of 'face' (Hwang 1987), this would be considered by the Chinese as being a loss of self-control and thus viewed negatively.

\subsection{The role of boundary spanners}

The above arguments have shown that 'cultural barriers' and embeddedness in different institutional contexts can create massive problems in communication within joint venture 
operations, as well as in relations with local suppliers. Because of these obstacles, those who have the capability to be network builders in and mediators between both cultures are of great importance in the long-term success of a joint venture (Coe and Bunnell 2003). These boundary spanners might be the first ones to form a larger transnational community within the Shanghai automobile industry cluster. The findings from our research suggest that there are boundary spanners on each side of the joint ventures which have been successful to varying degrees.

(i) Chinese boundary spanners: It is often assumed that Chinese managers will increasingly be given responsibility for the operations of a joint venture. A recent survey supports this assumption (Depner and Dewald 2004). The managers we have met in such positions were relatively few. All of them had spent several years in Germany and had studied or lived there (Interviews 1, 14, 43, 45). Their advantage is that they know both languages and cultural contexts and are able to alternate between different modes of interaction. Theoretically, they are extremely well suited in establishing communication between the German and Chinese sides, solving conflicts and circulating important knowledge. They are also able to effectively communicate with the German headquarters and alternate between different styles of negotiation, depending on whether their counterparts are Germans or Chinese.

Despite the enormous potential these boundary spanners have, their power within the joint ventures often appears limited. Their problem seems to be that they do not fully belong to either side. The Chinese co-workers are skeptical in that they believe such individuals may be too supportive of the German side, while the Germans, especially executives from the headquarters, do not include them in all strategic decision-making. Some of the Chinese boundary spanners mentioned that they wish the German headquarters would listen to them more carefully and give them more power in decision-making (Interviews 1, 14, 15, 45). 
(ii) German boundary spanners: German boundary spanners have typically adapted to the Chinese business context quite well and would voluntarily stay for a much longer period of time. Two managers, for instance, married Chinese women and have become increasingly familiar with Chinese customs and life-styles (Interviews 2, 12). Some of these boundary spanners have studied Sinology at a German university. Others have participated in special training programs to prepare them for future jobs in China, consisting of a language course and work placement for several months in a German firm in China (Interviews 5, 22, Case study 3). Another group of Germans had no special preparation before going to China but had international work experience. They had proven that they are able to adjust to a new cultural context and cope with it successfully (Interviews 16, 20). One manager of this latter group mentioned that there was a lot of distrust between him and his Chinese counterparts when he started his term in Shanghai. Over time, however, they began to exchange gifts and developed close relationships. This happened because the German manager made an effort to participate in Chinese social events and, among other things, invited his partners for dinner parties at his home (Case study 3).

Not all Germans interviewed in Shanghai can be viewed as active boundary spanners. They are under strong pressure from different sides. On the one hand, they have to deal with customers which require them to drastically cut costs. On the other hand, they have to follow the strategies and guidelines of their German parents. Further, they have to act and interact in complex Chinese institutional settings and a very dynamic industry context. In general, we observed that the motivation to understand and follow the rules of the Chinese side and to become active boundary spanners was low when the German personnel at the Shanghai operations was relatively large or when the managers knew that they were going to leave the city soon. 


\section{Conclusions}

In our analysis of the automobile industry in Shanghai, we have provided evidence that it is useful to employ a cluster concept to analyze the dynamics of production organization in a multinational context, especially if we aim to analyze the consequences of this development in a particular region. In the case of the automobile industry, this approach complements a global-commodity-chain or a global-production-network analysis. In choosing this approach, we found that it is necessary to emphasize those cluster dimensions which are sometimes neglected in the cluster literature, i.e. issues related to the role of culture, institutions and power and how they shape economic action and interaction. The inter-cultural context of automobile production in Shanghai, together with the importance of the role of policy and planning in the establishment of this industry, provided an interesting case study to apply this approach.

Overall, the establishment of the Shanghai automobile industry cluster has been largely initiated by international automobile producers, in our case VW, making a strategic move to extend their production system and market reach to China. The development of the cluster has been strongly supported by local and national policy makers. As a result of this, a focal cluster is developing which is characterized by a growing vertical dimension of suppliers and service providers. These have been required by VW to establish production in China, to fulfill localcontent regulations which were demanded by the Chinese government. The horizontal cluster dimension is still in a stage of infancy at this point but is changing quickly as GM has also established production in the region and attracts its own suppliers.

The complex relationships between economic development and politics become obvious through the role of SAIC, the dominant Chinese actor in the automobile industry. SAIC is largely owned by the municipality of Shanghai and is thus shaped by the city's general policies and strategies with respect to future development. At the same time, SAIC is involved 
in a large number of joint ventures with foreign automobile firms and parts producers, serving to closely intertwine economic and political aspects. What makes foreign direct investments in Shanghai's automobile industry even more complicated is that the conventions, rules, norms and expectations in human interaction are different from those which the firms are used to. This, in turn, effects the organization of production and labor processes within and between firms and the ways how firms can get knowledge about their local markets. The successful establishment of inter-cultural communication in the Shanghai automobile industry cluster therefore requires the development of a shared institutional context which enables interaction and knowledge creation. It also requires the development of methods and routines to control production and pass on orders and messages effectively within the production system over large distances.

We have shown how German firms import formal institutions to the Shanghai context and create new institutions to enable effective intra-firm communication and interaction with local suppliers and markets. We argue that network builders and boundary spanners, especially those originating from transnational communities, can become quite important in overcoming problems and mediating between different positions in an inter-cultural context. Their ability to stimulate communication might, in fact, determine the long-term success of such investments. At present, many new operations in the Shanghai automobile industry might still suffer from some problems and inefficiencies. This is quickly changing, however, as Shanghai develops into an important cluster of automobile production and firms learn to adjust to the local conditions at hand.

This paper also indicates the need in economic geography to go beyond the analysis of interfirm relationships to include inter-personal interaction. Similar to the recent discussion about projects, the discussion on boundary spanners and network builders presented here shows that the success of large multinational firms may be partially dependent on the capabilities of few 
core individuals - not necessarily at the top of the hierarchy - directing and coordinating information and knowledge flows in multinational, inter-cultural production arrangements.

\section{References}

Abo, T. 1996. The Japanese production system: the process of adaptation to national settings. In Boyer, R. and Drache, D. (eds.): States against Markets. The Limits of Globalization. pp. 136-154. London, New York: Routledge.

Allen, J. 1997. Economies of power and space. In Lee, R. and Wills, J. (eds.): Geographies of Economies. pp. 59-70. London: Arnold.

Amin, A. and Thrift, N. 1995. Living in the global. In Amin, A. and Thrift, N. (eds.): Globalization, Institutions, and Regional Development in Europe. pp. 1-22. Oxford, New York: Oxford University Press.

Automotive Resources Asia 2004. China Car Market News Release December 2003 (URL: http://www.autoresources-asia.com, 12.03.2004).

Bathelt, H. 2002. The re-emergence of a media industry cluster in Leipzig. European Planning Studies 10: 583611.

Bathelt, H. and Depner, H. 2003. Innovation, Institution und Region: Zur Diskussion über nationale und regionale Innovationssysteme (Innovation, institution and region: a commentary on the discussion of national and regional innovation systems). Erdkunde 57: 126-143.

Bathelt, H. and Glückler, J. 2003. Toward a relational economic geography. Journal of Economic Geography 3: 117-144.

Bathelt, H. and Jentsch, C. 2002. Die Entstehung eines Medienclusters in Leipzig: Neue Netzwerke und alte Strukturen (The genesis of a new media industry cluster in Leipzig: new networks and old structures). In Gräf, P. and Rauh, J. (eds.): Networks and Flows: Telekommunikation zwischen Raumstruktur, Verflechtung und Informationsgesellschaft. pp. 31-74. Hamburg, Münster: Lit.

Bathelt, H. and Taylor, M. 2002. Clusters, power and place: inequality and local growth in time-space. Geografiska Annaler 84 B: 93-109.

Bathelt, H., Malmberg, A. and Maskell, P. 2004. Clusters and knowledge: local buzz, global pipelines and the process of knowledge creation. Progress in Human Geography 28: 31-56.

Berndt, C. 2003. El Paso del Norte ... Modernization utopias, othering and management practices in Mexico's maquiladora industry. Antipode 35: 264-285.

Björkman, I. and Kock, S. 1995. Social relationships and business networks: the case of western companies in China. International Business Review 4: 519-535.

Boeckler, M. and Lindner, P. 2000. Jüngere Tendenzen im Umgang mit Kultur und Region in der Wirtschaftsund Sozialgeographie (Recent tendencies on the role of culture and region in economic and social 
geography). In Bahadir, S. A. (ed.): Kultur und Region im Zeichen der Globalisierung (Culture and Region in the Age of Globalization). pp. 105-128. Neustadt/Aisch: Verlag Degener.

Boyer, R. 1998. Hybridization and models of production: geography, history and theory. In Boyer, R., Charron, E., Jürgens, U. and Tolliday, S. (eds.): Between Imitation and Innovation. The Transfer and Hybridization of Productive Models in the International Automobile Industry. pp. 23-56. Oxford: Oxford University Press.

Bresnahan, T., Gambardella, A. and Saxenian, A. 2001. 'Old economy' inputs for 'new economy' outcomes: cluster formation in the new Silicon Valleys. Industrial and Corporate Change 10: 835-860.

Casson, M. and Godley, A. 2000. Cultural Factors in Economic Growth. Berlin: Springer.

Cavallardo, D. 2001. Critical and Cultural Theory: Thematic Variations. London, New Brunswick (NJ): Athlone.

China Business Update 2001. China’s Automobile Industry Annual Report 2001. Amherst, Beijing: China Business Update.

Clegg, S. 1989. Frameworks of Power. London: Sage.

Coe, N. M. and Bunnell, T. G. 2003. 'Spatializing' knowledge communities: towards a conceptualisation of transnational innovation networks. Global Networks 3: 437-456.

Cohen, W. M. and Levinthal, D. A. 1990. Absorptive capacity: a new perspective on learning and innovation. Administrative Science Quarterly 35: 128-152.

Cooke, P. 1999. The co-operative advantage of regions. In Barnes, T. J. and Gertler, M. S. (eds.): The New Industrial Geography: Regions, Regulation and Institutions. pp. 54-73. London: Routledge.

Cooke, P. and Morgan, K. 1998. The Associational Economy. Oxford: Oxford University Press.

Crang, P. 1997. Cultural turns and the (re)constitution of economic geography. In Lee, R. and Wills, J. (eds.): Geographies of Economies. pp. 3-15. London, New York: Arnold.

Depner, H. 2003. Globale Produktionsnetze und Entwicklungsländer: Die Automobilindustrie in China (Global production networks and development countries: the case of the automobile industry in China). Praxis Geographie 33 (2): 22-25.

Depner, H. and Dewald, U. 2004. Globale Netzwerke und lokale Partner: Deutsche Automobilzulieferer und der Wachstumsmarkt China (Global Networks and Local Partners: German Automobile Suppliers and the Emerging Chinese Market). SPACES 2004-02. Marburg: Fachbereich Geographie, Philipps-Universität Marburg (URL: http://www.uni-marburg.de/geographie/spaces, 20.03.2004).

Dicken, P. 2003. 'Placing' firms: grounding the debate on the 'global' corporation. In Peck, J. and Yeung, H. W.-c. (eds.): Remaking the Global Economy: Economic-Geographical Perspectives. pp. 27-44. London: Sage.

Dicken, P., Kelly, P. F., Olds, K. and Yeung, H. W.-c. 2001. Chains and networks, territories and scales: towards a relational framework for analysing the global economy. Global Networks 1: 89-112.

Florida, R. and Kenney, M. 1991. Transplanted organizations: the transfer of Japanese industrial organization to the US. American Sociological Review 56: 381-398. 
Fujita, M., Krugman, P. and Venables, A. J. 1999. The Spatial Economy. Cities, Regions and International Trade. Cambridge (MA): MIT Press.

Gereffi, G. 1994. The organization of buyer-driven global commodity chains: how US retailers shape overseas production networks. In Gereffi, G. and Korzeniewicz, M. (eds.): Commodity Chains and Global Capitalism. pp. 95-122. Westport (CT): Praeger.

Gereffi, G. 1999. International trade and industrial upgrading in the apparel commodity chain. Journal of International Economics 48: 37-70.

Gereffi, G. and Korzeniewicz M. 1990. Commodity chains and footwear exports in the semiperiphery. In Martin, W. G. (ed.): Semiperipheral States in the World-Economy. pp. 45-68. Westport (CT): Greenwood Press.

Gertler, M. S. 1993. Implementing advanced manufacturing technologies in mature industrial regions: towards a social model of technology production. Regional Studies 27: 665-680.

Gertler, M. S. 1995. 'Being there': proximity, organization, and culture in the development and adoption of advanced manufacturing technologies. Economic Geography 71: 1-26.

Gertler, M. S. 2001. Best practice? Geography, learning and the institutional limits to strong convergence. Journal of Economic Geography 1: 5-26.

Gertler, M. S. 2004. Manufacturing Culture: The Institutional Geography of Industrial Practice. New York: Oxford University Press.

Giuliani, E. 2002. Cluster Absorptive Capability: An Evolutionary Approach for Industrial Clusters in Developing Countries. Paper presented at the DRUID Summer Conference on 'Industrial Dynamics of the New and Old Economy -- Who is Embracing Whom?' in Copenhagen \& Elsinore (URL: http://www.druid.dk/conferences/summer2002/Papers/GIULIANI.pdf, 20.03.2004).

Glückler, J. and Bathelt, H. 2003. Zur Bedeutung von Ressourcen in der relationalen Wirtschaftsgeographie: Vom Substanzkonzept zur relationalen Perspektive (Substantive and relational conceptions of resources in relational economic geography). Zeitschrift für Wirtschaftsgeographie 47: 249-267.

Gordon, I. R. and McCann, P. 2000. Industrial clusters: complexes, agglomeration and/or social networks. Urban Studies 37: 513-532.

Grabher, G. 2001. Ecologies of creativity: the village, the group, and the heterarchic organisation of the British advertising industry. Environment and Planning A 33: 351-374.

Grabher, G. 2002. Cool projects, boring institutions: temporary collaboration in social context. Regional Studies 36: 205-214.

Granovetter, M. 1973. The strength of weak ties. American Journal of Sociology 78: 1360-1380.

Hall, P. A. and Soskice, D. 2001. An introduction to varieties of capitalism. In Hall, P. A. and Soskice, D. (eds.): Varieties of Capitalism: The Institutional Foundations of Comparative Advantage. pp. 1-68. Oxford, New York: Oxford University Press.

Harwit, E. 1992. Foreign passenger car ventures and Chinese decision making. The Australian Journal of Chinese Affairs 28: 141-166. 
Harwit, E. 2001. The impact of WTO membership on the automobile industry in China. China Quarterly 167: 655-670.

Henderson, J., Dicken, P., Hess, M., Coe, N. and Yeung, H. W.-c. 2002. Global production networks and the analysis of economic development. Review of International Political Economy 9: 436-464.

Hengenberg, T. 1999. Qualitätsmanagement in der Automobilindustrie (Quality management in the automobile industry). Deutsch-Chinesisches Wirtschaftsforum - Zeitschrift der Delegiertenbüros der Deutschen Wirtschaft in China 3: 18-19.

Hodgson, G. M. 1988. Economics and Institutions: A Manifesto for a Modern Institutional Economics. Cambridge: Polity Press.

Hodgson, G. M. 2003. The hidden persuaders: institutions and individuals in economic theory. Cambridge Journal of Economics 27: 159-175.

Hoon-Halbauer, S. K. 1999. Managing relationships within Sino-foreign joint ventures. Journal of World Business 34, 344-371.

Hösle, V. 2002. Was ist Kultur? (What is culture?) Think on 1: 12-19.

Hsu, J.-y. and Saxenian, A. 2000. The limits to guanxi capitalism: transnational collaboration between Taiwan and the US. Environment and Planning A 32: 1991-2005.

Humphrey, J. and Memedovic, O. 2003. The Global Automotive Industry Value Chain: What Prospects for Upgrading by Developing Countries? Sectoral studies series. Vienna: United Nations Industrial Development Organization (URL: http://www.unido.org/file-storage/download/?file_id=11902, 20.03.2004).

Humphrey, J. and Schmitz, H. 2002. How does insertion in global value chains affect upgrading in industrial clusters? Regional Studies 36: 1017-1027.

Hwang, K.-k. 1987. Face and favor: the Chinese power game. American Journal of Sociology 92: 944-974.

Jöns, H. 2003. Von Menschen und Dingen: Konstruktivistisch-kritische Anmerkungen zum (a)symmetrischen Akteurskonzept der Akteursnetzwerktheorie (Humans and non-humans: critical comments on the (a)symmetrical actor concept in actor-network theory). In Hasse, J. and Helbrecht, I. (eds.): Menschenbilder in der Humangeographie (Human Images in Human Geography). pp. 109-142. Oldenburg: Bibliotheks- und Informationssystem.

Kern, H. 1996. Vertrauensverlust und blindes Vertrauen: Integrationsprobleme im ökonomischen Handeln (Loss of trust and blind confidence in economic action). SOFI-Mitteilungen 24/1996: 7-14.

Kiefer, T. 1998. Volkswagen's Shanghai plant: between Chinese tradition and modernization strategy. In Boyer, R., Charron, E., Jürgens, U. and Tolliday, S. (eds.): Between Imitation and Innovation. The Transfer and Hybridization of Productive Models in the International Automobile Industry. pp. 342-360. Oxford: Oxford University Press. 
KPMG (Klynveld, Peat, Marwick and Goerdeler). 2003. China Automotive and Component Parts Market. Hong Kong: KPMG (URL:

http://www.kpmg.com.cn/Press\%20releases/KPMG_China_auto_industry_report03.pdf, 02.03.2004).

Krugman, P. 1991. Geography and Trade. Leuven: Leuven University Press \& Cambridge (MA), London: MIT Press.

Krugman, P. 2000. Where in the world is the 'new economic geography'? In Clark, G. L., Feldman, M. P. and Gertler, M. S. (eds.): The Oxford Handbook of Economic Geography. pp. 49-60. Oxford: Oxford University Press.

Lash, S. and Urry, J. 1994. Economies of Signs and Spaces. London: Sage.

Latour, B. 1986. The powers of association. In Law, J. (ed.): Power, Action and Belief: A New Sociology of Knowledge? pp. 264-280. London: Routledge \& Kegan Paul.

Lawson, C. 1999. Towards a competence theory of the region. Cambridge Journal of Economics 23: 151-166.

Lee, C. 2001. Chinas Automobilindustrie in der Globalisierung (Globalization processes in China's automobile industry). Berichte des Arbeitskreises Chinaforschung 15. Bremen: Institut für Weltwirtschaft und Internationales Management der Universität Bremen.

Lee, C., Chen, J. and Fujimoto, T. 1996. Different Strategies of Localization in the Chinese Auto Industry: The Cases of Shanghai Volkswagen and Tianjin Daihatsu. Working Paper for the MIT 1996 IMVP Sponsors Meeting in Sao Paulo.

Lipietz, A. 1987. Mirages and miracles: The crises of global Fordism. London: Verso.

Lorenz, E. 1999. Trust, contract and economic cooperation. Cambridge Journal of Economics 23: 301-315.

Lundequist, P. and Power, D. 2002. Putting Porter into practice? Practices of regional cluster building: evidence from Sweden. European Planning Studies 10: 685-704.

Lundvall, B.-Å. 1988. Innovation as an interactive process: from user-producer interaction to the national system of innovation. In Dosi, G., Freeman, C., Nelson, R. R., Silverberg, G. and Soete, L. L. G. (eds.): Technical Change and Economic Theory. pp. 349-369. London: Pinter.

Lundvall, B.-Å. and Maskell, P. 2000. Nation states and economic development - From national systems of production to national systems of knowledge creation and learning. In Clark, G. L., Feldman, M. P. and Gertler, M. S. (eds.): The Oxford Handbook of Economic Geography. pp. 353-372. Oxford: Oxford University Press.

Maillat, D. 1998. Vom 'Industrial District' zum innovativen Milieu: Ein Beitrag zur Analyse der lokalen Produktionssysteme (From industrial districts to innovative milieus: towards an analysis of territorial production systems). Geographische Zeitschrift 86: 1-15.

Mair, A., Florida, R. and Kenney, M. 1988. The new geography of automobile production: Japanese transplants in North America. Economic Geography 64: 352-373.

Malecki, E. J. 2000. Knowledge and Regional Competitiveness. Erdkunde 54: 334-351. 
Malmberg, A. and Maskell, P. 2002. The elusive concept of localization economies: towards a knowledge-based theory of spatial clustering. Environment and Planning A 34: 429-449.

Marshall, A. 1920. Principles of Economics. 8th edition. Philadelphia: Porcupine Press.

Marshall, A. 1927. Industry and Trade. A Study of Industrial Technique and Business Organization; and Their Influences on the Conditions of Various Classes and Nations. 3rd edition. London: Macmillan.

Martin, R. and Sunley, P. 2003. Deconstructing clusters: chaotic concept or policy panacea? Journal of Economic Geography 3: 5-35.

Maskell, P. 2001. Towards a knowledge-based theory of the geographical cluster. Industrial and Corporate Change 10: 921-943.

Maskell, P. and Malmberg, A. 1999a. The competitiveness of firms and regions: 'ubiquitification' and the importance of localized learning. European Urban and Regional Studies 6: 9-25.

Maskell, P. and Malmberg, A. 1999b. Localised learning and industrial competitiveness. Cambridge Journal of Economics 23: 167-185.

McKelvey, M. 1997. Using evolutionary theory to define systems of innovation. In Edquist, C. (ed.): Systems of Innovation: Technologies, Institutions and Organizations. pp. 200-222. London: Pinter.

Mitchell, D. 2000. Cultural Geography: A Critical Introduction. Malden, Oxford: Blackwell.

Mok, V. 1996. Industrial development. In Yeung, Y. M. and Sun, Y.-w. (eds.): Shanghai. Transformation and Modernization under China's Open Policy. pp. 199-223. Hong Kong: Chinese University Press.

Murdoch, J. 1995. Actor-networks and the evolution of economic forms: combining description and explanation in theories of regulation, flexible specialization, and networks. Environment and Planning A 27: 731757.

North, D. C. 1990. Institutions, Institutional Change and Economic Performance. Cambridge: Cambridge University Press.

Ó hUallacháin, B. and Wasserman, D. 1999. Vertical integration in a lean supply chain: Brazilian automobile component parts. Economic Geography 75: 21-45.

Oinas, P. 1997. On the socio-spatial embeddedness of business firms. Erdkunde 51: 23-32.

Owen-Smith, J. and Powell, W. W. 2004. Knowledge networks as channels and conduits: the effects of spillovers in the Boston biotechnology community. Organization Science 15: 2-21.

Porter, M. E. 1990. The Competitive Advantage of Nations. New York: Free Press.

Porter, M. E. 1998. Clusters and the new economics of competition. Harvard Business Review 76 (NovemberDecember): 77-90.

Porter, M. E. 2000. Locations, clusters, and company strategy. In Clark, G. L., Feldman, M. P. and Gertler, M. S. (eds.): The Oxford Handbook of Economic Geography. pp. 253-274. Oxford: Oxford University Press.

Porter, M. E. 2002. Einstellungen, Werte, Überzeugungen und die Mikroökonomie des Wohlstands (Attitudes, values, convictions and the microeconomics of welfare). In Harrison, L. E. and Huntington, S. P. (eds.): 
Streit um Werte. Wie Kulturen den Fortschritt prägen (Culture Matters). pp. 37-55. Hamburg: Europa Verlag.

Power, D. 2002. 'Cultural industries' in Sweden: an assessment of their place in the Swedish economy.

Economic Geography 78: 103-127.

Richter, F.-J. and Vettel, K. 1996. Changing China: The Car Supplier Industry and its Future. Soziale und Wirtschaftliche Studien über Japan/ Ostasien. Occasional Paper 105. Berlin: Ostasiatisches Seminar der Freien Universität Berlin.

Roland Berger Strategy Consultants. 2001. 10 Mega Trends of the Chinese Automotive Industry after WTO Entry. Roland Berger Study. Shanghai: Roland Berger Strategy Consultants.

Sadler, D. 1994. The geographies of just-in-time: Japanese investment and the automotive components industry in Western Europe. Economic Geography 70: 41-59.

SAIC - Shanghai Automotive Industry Corporation. 2002. Annual Report 2001. Shanghai.

Saxenian, A. L. 1994. Regional Advantage. Culture and Competition in Silicon Valley and Route 128. Cambridge (MA), London: Harvard University Press.

Saxenian, A. and Hsu, J.-y. 2001. The Silicon Valley-Hsinchu connection: technical communities and industrial upgrading. Industrial and Corporate Change 10: 893-920.

Sayer, A. 1997. The dialectic of culture and economy. In Lee, R. and Wills, J. (eds.): Geographies of Economies. pp. 16-26. London, New York: Arnold.

Schamp, E. W. 1995. The German automobile production system going European. In Hudson, R. and Schamp, E. W. (eds.): Towards a New Map of Automobile Manufacturing in Europe? New Production Concepts and Spatial Restructuring. pp. 93-116. Berlin, Heidelberg: Springer.

Schoenberger, E. 1999. The firm in the region and the region in the firm. In Barnes, T. J. and Gertler, M. S. (eds.): The New Industrial Geography: Regions, Regulation and Institutions. pp. 205-224. London: Routledge.

Scott, A. J. 1988. New Industrial Spaces: Flexible Production Organization and Regional Development in North America and Western Europe. London: Pion.

Scott, A. J. 1998. Regions and the World Economy: The Coming Shape of Global Production, Competition, and Political Order. Oxford, New York: Oxford University Press.

Scott, J. 2001. Power. Cambridge, Oxford: Polity Press.

Shanghai Daily 2002. Chinese-car sales rise 40 \%. Shanghai Daily, 10.9.2002: p. 2.

Sit, V. F. S. and Liu, W. 2000. Restructuring and spatial change of China's auto industry under institutional reform and globalization. Annals of the Association of American Geographers 90, 653-673.

Smith, A. 2003. Power relations, industrial clusters, and regional transformations: pan-European integration and outward processing in the Slovak clothing industry. Economic Geography 79: 17-40. 
Sofer, M. and Schnell, I. 2002. Over- and under-embeddedness: failures in developing mixed embeddedness among Israeli Arab entrepreneurs. In Taylor, M. and Leonard, S. (eds.): Embedded Enterprise and Social Capital: International Perspectives. pp. 207-224. Aldershot: Ashgate.

Storper, M. 1995. The resurgence of regional economics, ten years later. European Urban and Regional Studies 2: 191-221.

Storper, M. 1997. The Regional World. Territorial Development in a Global Economy. New York, London: Guilford.

Storper, M. and Venables, A. J. 2004. Buzz: the economic force of the city. Journal of Economic Geography 4: forthcoming.

Taylor, M. 1995. The business enterprise, power and patterns of geographical industrialisation. In Conti, S., Malecki, E. J. and Oinas, P. (eds.): The Industrial Enterprise and its Environment: Spatial Perspectives. pp. 99-122. Aldershot: Ashgate.

Taylor, M. 2000. Enterprise, power and embeddedness: an empirical exploration. In Vatne, E. and Taylor, M. (eds.): The Networked Firm in a Global World: Small Firms in New Environments. pp. 199-233. Aldershot, Burlington: Ashgate.

Thrift, N. J. 1996. Spatial Formations. London: Sage.

Thrift, N. 2000. Pandora's box? Cultural geographies of economies. In Clark, G. L., Feldman, M. P. and Gertler, M. S. (eds.): The Oxford Handbook of Economic Geography. pp. 689-704. Oxford: Oxford University Press.

Tierney, C. 2003. Joint ventures in China expose Big 3 to piracy. The Detroit News, 08.12.2003 (URL: http://www.detnews.com/2003/specialreport/0312/08/a01-344135.htm, 02.02.2004).

Tracey, P., Clark, G. L. and Lawton Smith, H. 2002. Cognition, Learning and European Regional Growth: An Agent-Centred Perspective on the 'New' Economy. School of Geography Working Paper 02-10. Oxford: School of Geography and the Environment, University of Oxford.

Uzzi, B. 1997. Social structure and competition in interfirm networks: the paradox of embeddedness. Administrative Science Quarterly 42: 35-67.

van den Bosch, F. A. J., Volberda, H. W. and de Boer, M. 1999. Coevolution of firm absorptive capacity and knowledge environment: organizational forms and combinative capabilities. Organizational Science 10: 551-568.

Vwd: Asien. 2003a. GM: Kfz-Absatz verdreifacht (GM: car sales have tripled). 4/2003: p. 4.

Vwd: Asien. 2003b. VW hat Pkw-Absatz um 43 Prozent gesteigert (VW increases its number of cars sold by $43 \%) .6 / 2003$ : p. 3.

Vwd: Asien. 2004. VW-Partner SAIC will eigene Marke fertigen (SAIC, the joint venture partner of VW, wants to produce its own brand). 3/2004: p. 2 .

Wang, H. 2001. Weak State, Strong Networks. The Institutional Dynamics of Foreign Direct Investment in China. Oxford: Oxford University Press. 
Whitley, R. 1999. Divergent Capitalisms: The Social Structuring and Change of Business Systems. Oxford: Oxford University Press.

Whitley, R. 2000. The institutional structuring of innovation strategies: business systems, firm types and patterns of technical change in different market economies. Organization Studies 21: 855-886.

Yang, X. 1995. Globalization of the Automobile Industry. The United States, Japan and the People's Republic of China. Westport (CT): Praeger.

Yeung, H. W.-c. 1994. Critical reviews of geographical perspectives on business organizations and the organization of production: towards a network approach. Progress in Human Geography 18: 460-490.

Yeung, H. W.-c. 2000. Embedding foreign affiliates in transnational business networks: the case of Hong Kong firms in Southeast Asia. Environment and Planning A 32: 201-222.

Yeung, H. W.-c. and Lin, G. C. S. 2003. Theorizing economic geographies of Asia. Economic Geography 79: $107-128$.

Zeng, G. 2000. The financial crisis in Asia and the modification of economic structure in Shanghai. Asian Geographer 19: 37-48.

Zhu, G., Speece, M. W. and So, S. L. M. 1998. Conflicts in Sino-European joint ventures. In Selmer, J. (ed.): International Management in China. pp. 13-28. London: Routledge. 
Table 1. Total number of cars produced in China and Shanghai Volkswagen's share, 1990 2003 (Sources: Harwit 2001, China Business Update 2001, Shanghai Daily 2002, Vwd: Asien 2003b, Automotive Resources Asia 2004)

\begin{tabular}{lcccccccc}
\hline & 1990 & 1992 & 1994 & 1996 & 1998 & 2000 & 2002 & 2003 \\
\hline Total & 40,000 & 162,725 & 250,333 & 391,099 & 507,103 & 604,677 & $1,225,240^{*}$ & $2,082,581^{*}$ \\
SVW & 18,537 & 65,000 & 115,326 & 200,222 & 235,000 & 253,120 & $301,095^{*}$ & $396,023^{*}$ \\
$\begin{array}{l}\text { SVW's } \\
\text { share of the } \\
\text { total }\end{array}$ & $46.3 \%$ & $39.9 \%$ & $46.1 \%$ & $51.2 \%$ & $46.3 \%$ & $41.9 \%$ & $24.6 \%$ & $19.0 \%$ \\
\hline
\end{tabular}

Note: * number of cars sold 
Figure 1. Financial control over other companies as exercised by the Shanghai Automotive Industrial Corporation, 2003 (Sources: SAIC 2002, survey results)

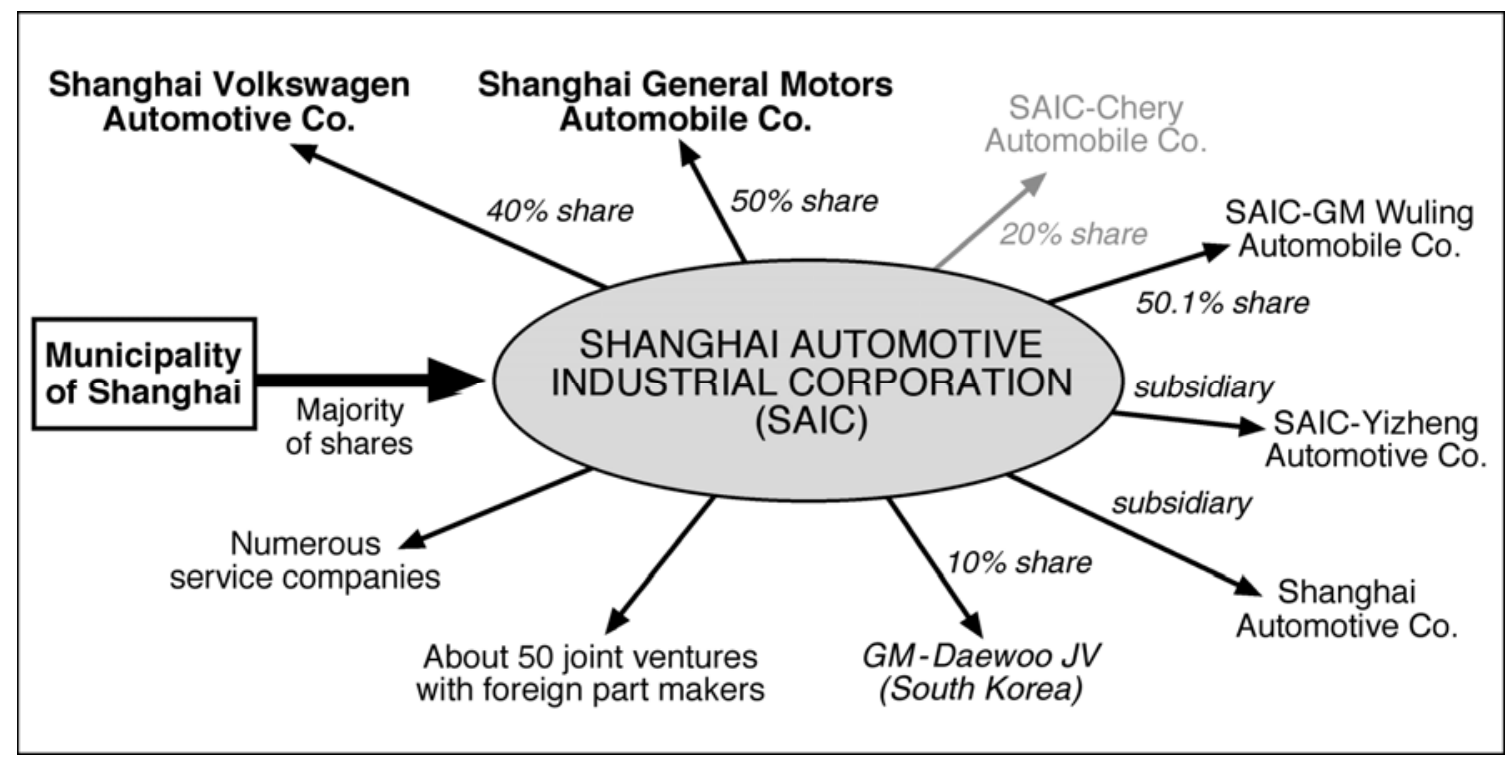


Figure 2. Location and year established of selected suppliers in the Shanghai automobile industry cluster

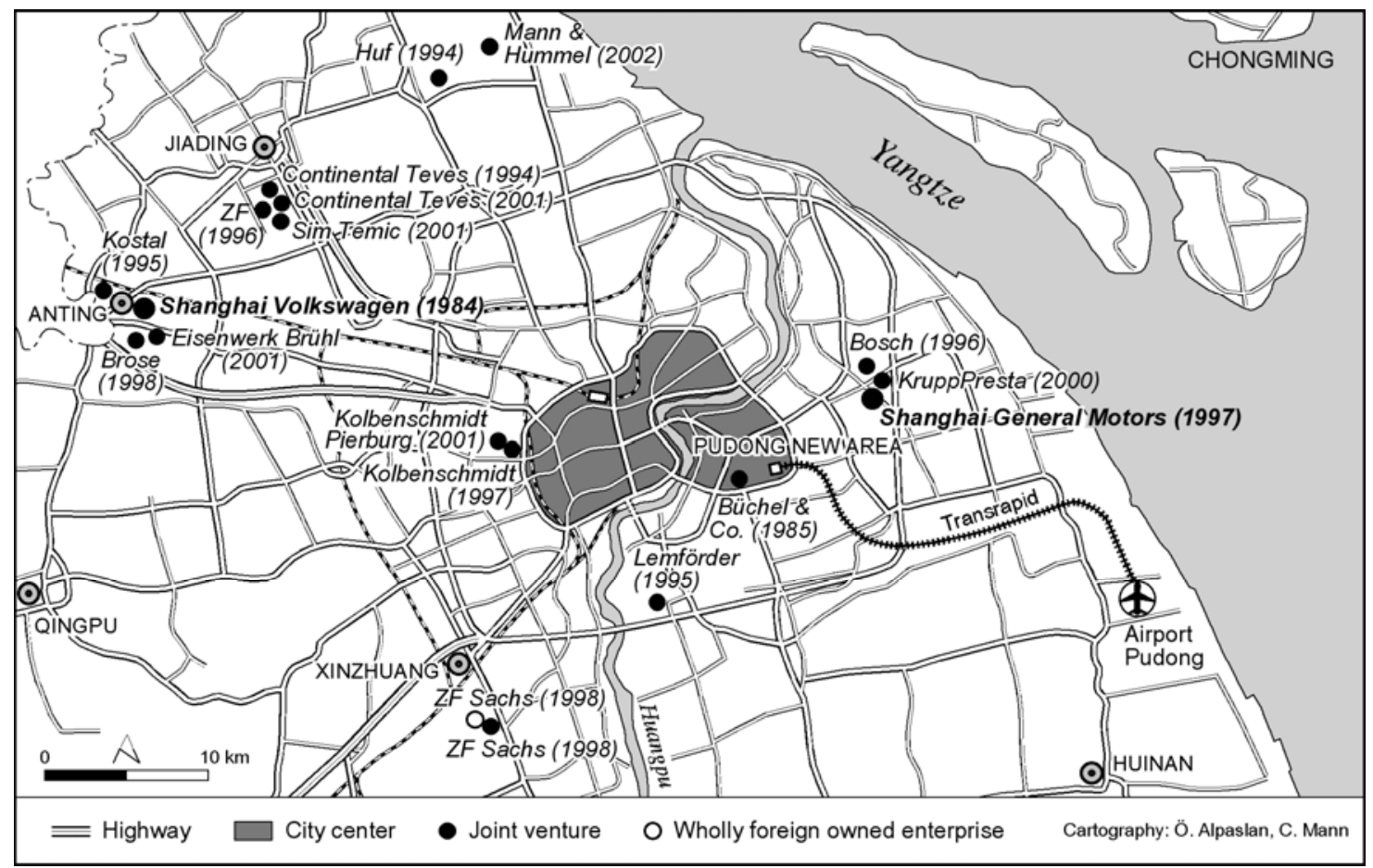


Figure 3. Idealized structure of the automobile industry cluster in Shanghai and its external linkages

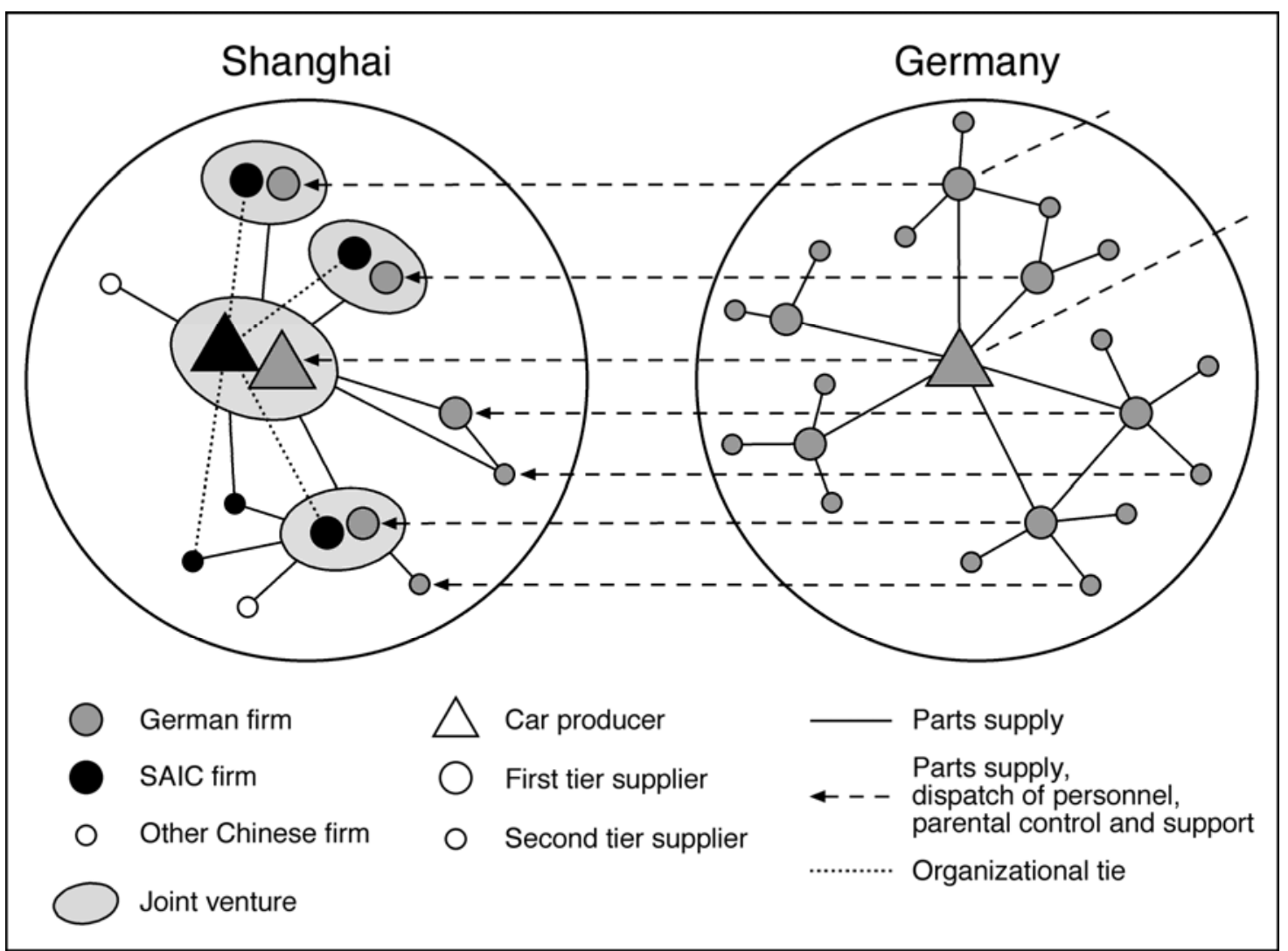

